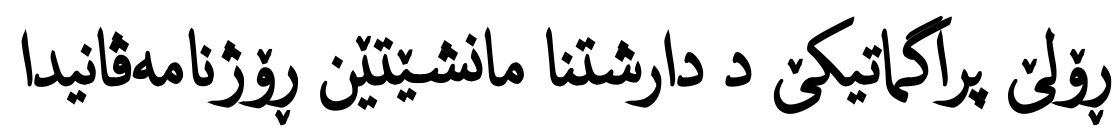

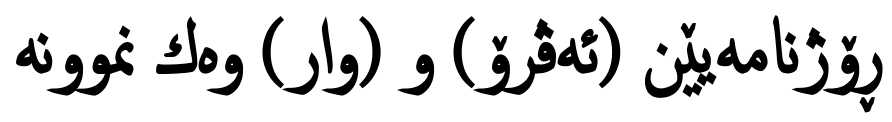

د. شيّرزاد سهبرى على (وانهبيّز ل زانكويا نهوروز)

بروّفيسور هاريكار

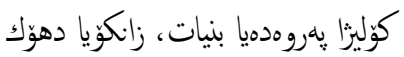

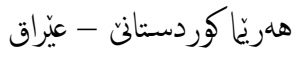

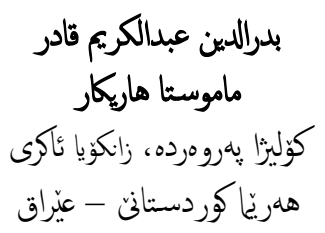

كورتى

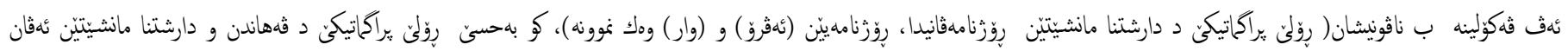

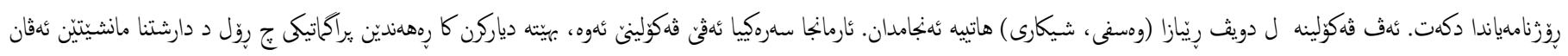

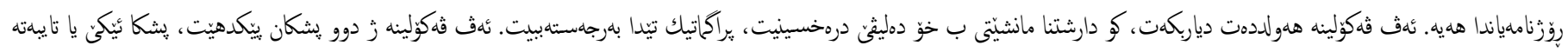

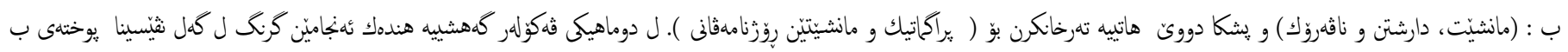

زمانّ عهرمبى و ئينكليزى.

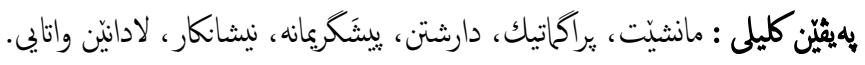

\section{كهرهستى فهكولينى}

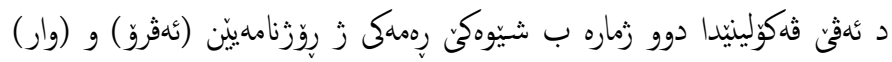

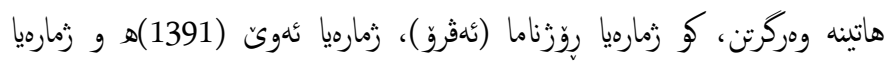
روّزَنامهيا (وار)، بريتييه ز زماريا (1048).

ريّيازا فهكولينئ

ئهث ثةكولينه ل دويث ريّيازا (وهسفى، شيكارى) هاتييه ئنجامدان.

برسياريّن ثهكولينى

ئهف ثفكولينه هلولددهت بهرسثى ل سهر ئهفان يرسياران بدهت :

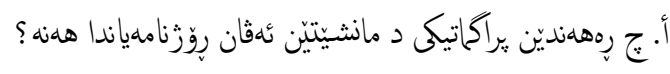

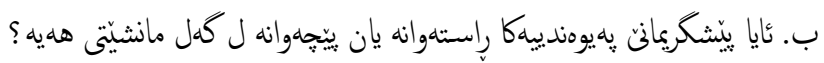

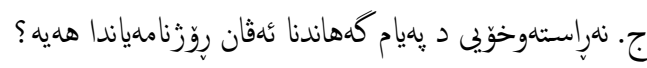

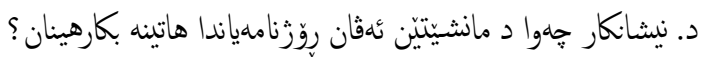

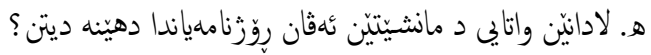

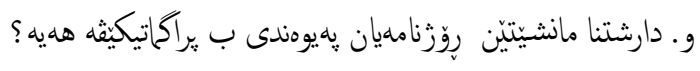

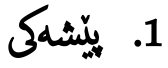

ناقونيشاني ثدكوليني

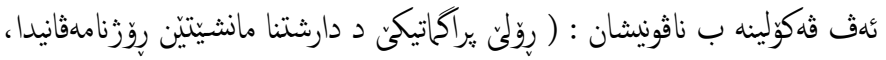

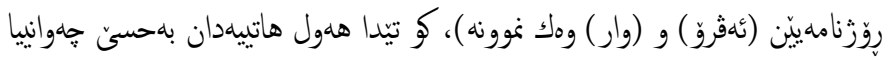

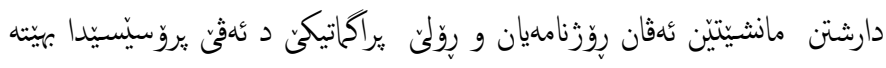

كرنكييا ثهفئ ثذكولينى

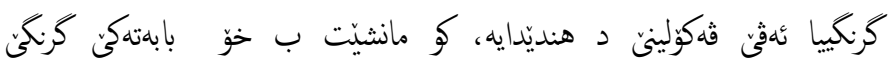

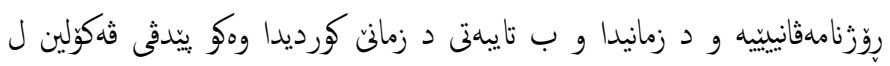

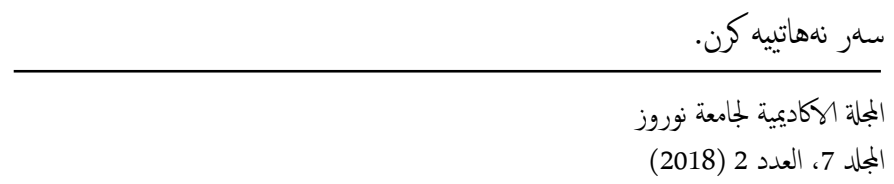

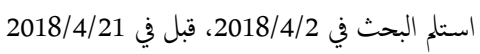
ورقة بحث منتظمة نشرت في 2018/6/14 في لركب

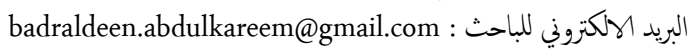
حقوق الطبع والنشر (؟) 2017 أسهاء المؤلفين. هذه مقالة الوصول اليها مفتوح موزعة تحت رخصة

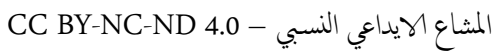




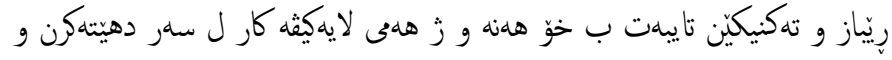

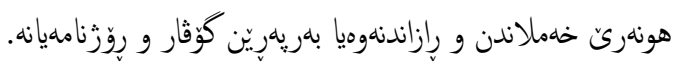

2. بيّناسهيا مانثيّتى

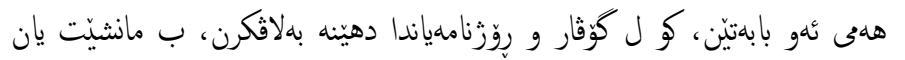
ناقونيشانهى دهينه دياركرن، زبلى كورتييا دمنكوباسان نهبت، كو تايبهمندييا ئهوان يا

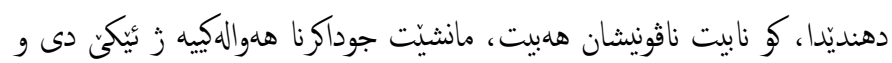

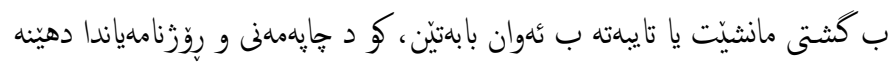
بهلاقكرن (نةزاد، - ، 95). كهلهك يِّناسه بو مانشيّتى ييّن هاتينهكرن، جونكى زبلى

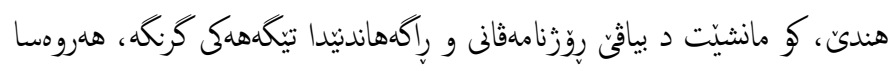
د زماثفانييّزيديا ثهولين ل سهر دهينه نثنجامدان و ب كهلهك شيّوازان هاتييه

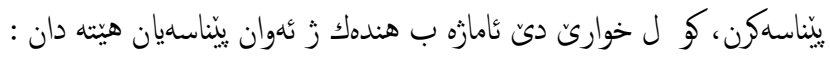

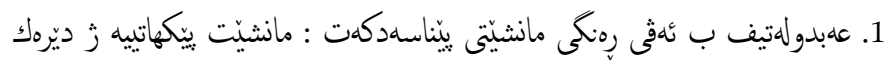
يان حهند ديرّكان، كو ب ريّكا مهزنكرنا يِيتّن ئهوان هاتينه ليكدان، دكفيثنه بهراهييا بابهت يان مزارهك هلوالى و دبيته يوختهيا ثندوى بابهتى يان هلوالى (مزه،

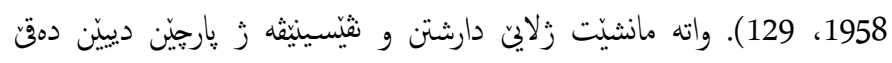

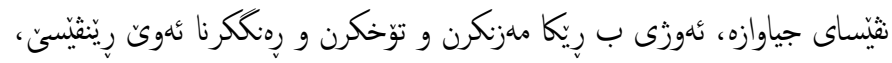
ياكو مانشيَت ينّ هاتيه نثنسين.

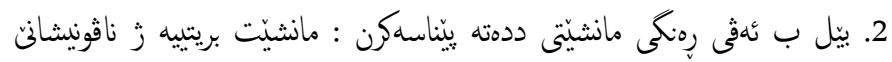

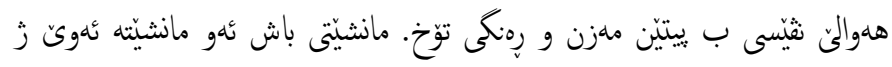

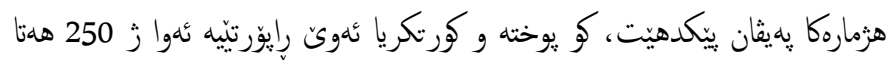

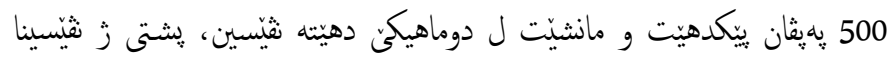

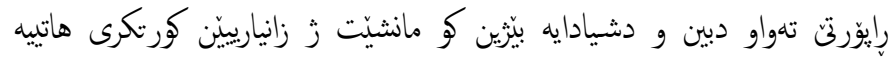
دارشتن(Bell، (158،1991) - (158). 3. ئابادى ب ئدقى رِنكى مانشيّتى يِيناسهدكةت : مانشيْت يوختهيا كرنكترين

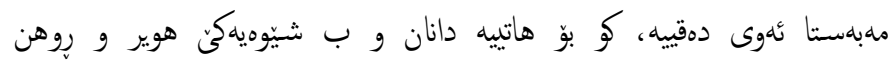
يبيشكنيشكربت (نَابادى، 2005، 69).

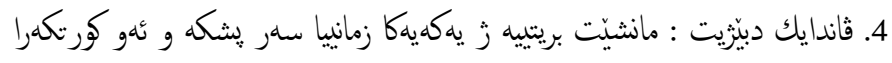
بابهتى هلميييه (2007،Vandijk، 187،
ر. ئهريّ دارشتن و قهباريّ مانشيتى دهليثى درهخينيت، كو رههنديّن يراكماتيكى

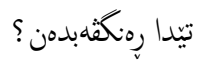

\section{بشكين ثهكوليني}

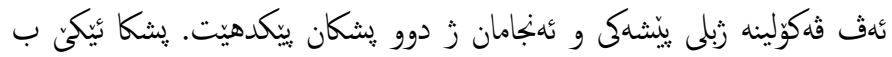

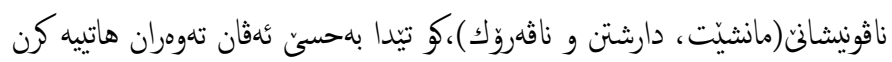

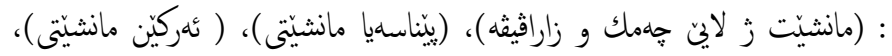
(تايبهمهنديييّن زمانييّن مانشيّتى)، (دارشتنا مانشيّتى)، (مانشيّت و وئزراندنا

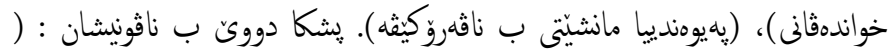

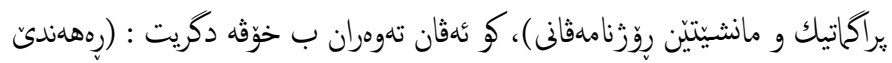

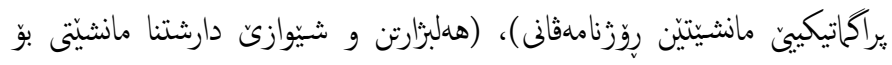

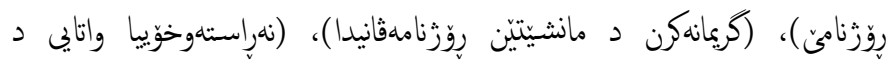

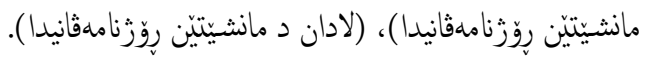
بشكا ثينكئ : مانشيّت، دارشتن و نافروَك

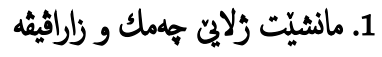

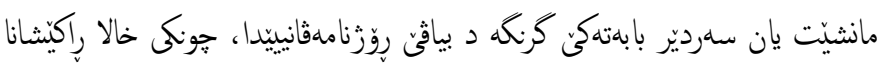

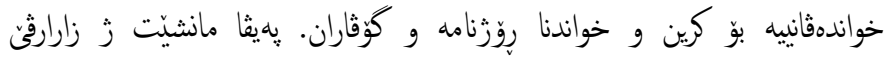
Sن فهرهنى هاتييه وهركرتن، كو ب وانايا سهرهحكى كراسى (Manchette)

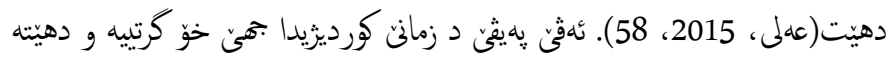
بكارهينان، سهروراى هلبوونا ههندين يهيث و زاراثين دى، وهك : (ناثويشان، سهردير ، سهربابهت، ناقيى وتاريّ... هتد)، كو بوّ هلمان مهبهست د زمانت كورديدا دهينه بكارهينان. د زمانَ ئنكليزيدا بهيثين ( Banner، Caption،Headline)

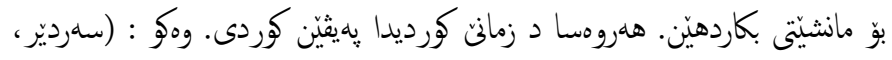
ناوى وتار، سهربابهت، مانشيّت، سهرديرى كموره، سهر وتارى هِهند

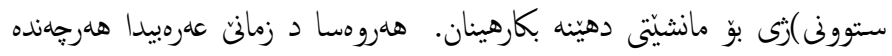

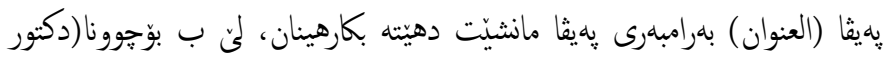
عهبدولهتيف حلمزه)ى، كو دبيّزيت : "ئهكةر مه بثيت وهركيرِانهكا راست و دروست

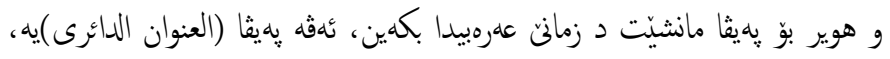

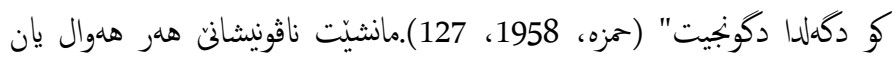

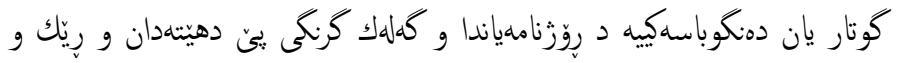




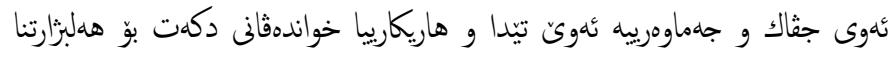

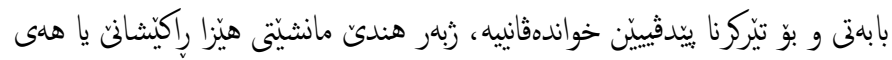

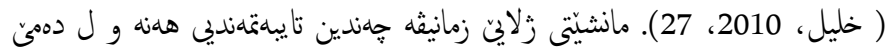

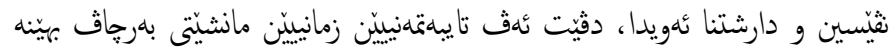

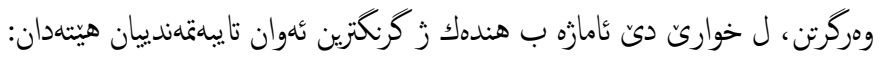

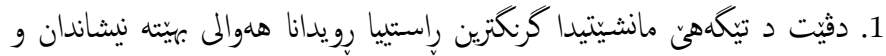
زمةقكرن.

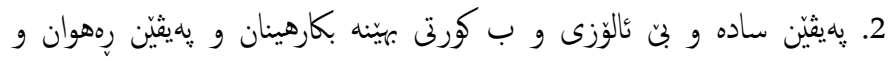

بارنياس بيينه بكارهينان

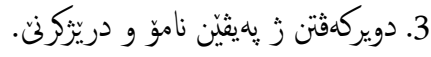

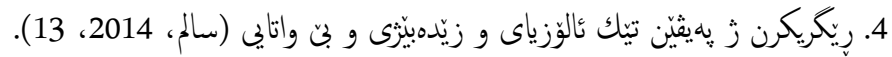
ئانكو دقيت مانشيَت يا روهن و راست بيت و دويربيت ز شاشيييّن واتايى. 5. مانشيّت بشيَت كريكهريبها مهزن ل سهر خواندهثانى بكةت. 6. دثيّت مانشيّت ين كونجاى بيت بوّ ندوى جه و بياقى تيندا كاردكهت.

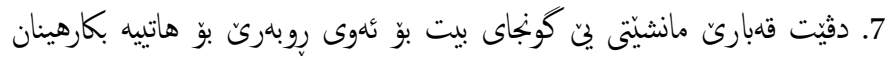
.(99،2006،Aggarwal)

8. مانشيّتا بنَ(كار ) زوّرجاران دبيته دروشم و نهشيّت يهاياقى ب دروستى بكهينيت.

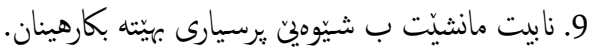
10. هلمان بهيث تيّدا دووباره نهبنهفه (كهريى، 2006، 73-74). 11. جهختكرن ل سهر دهربينيّن مانشيتى و بكارهينانا ثنوان زاراثين كونجاى و

$$
\text { رِيّكويبك و مفادار بوّ كههاندنا يهياما مانشيّتى. }
$$

12. يُشخستن و كرنكيدان ب كارئ بهردوام د مانشيتيدا، داكو خواندهان ومسا هلست بكهت، كو ينّ د ناث بابهتيدا و بابهت ينّ كةر و هلنوكهييه.

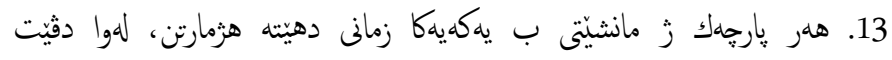

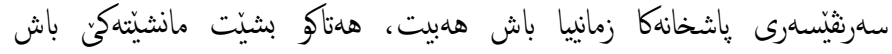
يِيْشكنشبكةت (حمزه، 1958، 130-131). دشياندايه بييتنه كوتن، كو مانشيّت

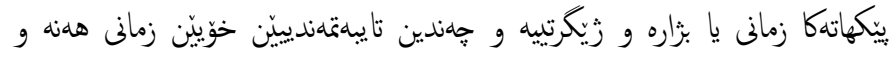

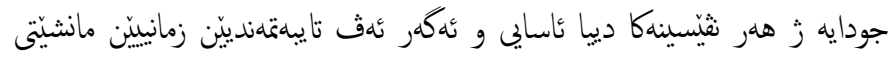

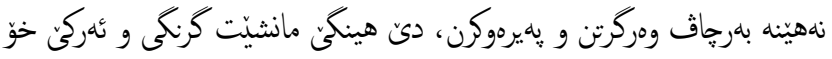

5. توراو ب ئهقى رِنكى يِّناسهيا مانشيتى دكهت و دبيّزيت : مانشيّت ناقونيشانهك، كو ل سهر هلوالى دكهثيت و خواندهثانى بوّ بابهتى و كرنكييا ندوى رإدكيشيت (Turow،2009،305). ز زئنجامي ئدقان هلى يِيناسهيّن ل سهرى

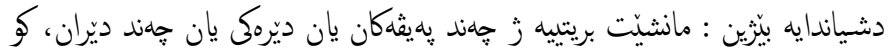

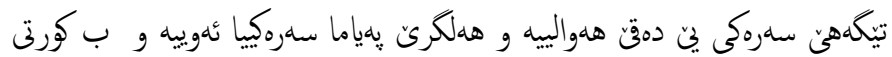
هاتييه دارشتن و هلكرا واتايهكا فراوانا وتارهكي يان هلوالهكييه و هلبثرارتنا سهركفثى يا مانشيّتى، كاريكةرى و وروورزاندني ل دمث خواندهفانى دروستدكةت.

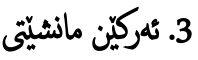

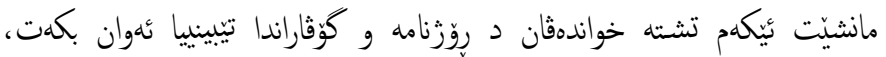

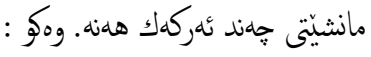

1. مانشيّت هاريكارييا خواندهثانى دكةت، كو برياريّ بدهت، كا بهردوام بيت ل سهر خواندنا وتارىى يان دمق هممييى يان نه. 2. مانشيّتى سهركفثى خواندهانى رِازيدكةت، كو ومخت و دمعي خو بوٌ خواندنا

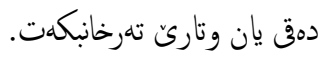
3. دثيت مانشيّت ين سهرنجراكيش و راست بيت، هلروهسا ينّ زهق و ب هوَش بهيّته دانان، جونكى مانشيّت دبنه ئهكر كرينا رِوَزنامه و كوُقاران. 4. دثيت هلر مانشيتهك كورتككرا ئدوى هدوالى بيت ئدوا د دويثدا دهيت (101)

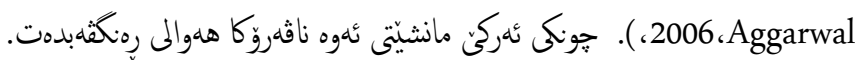

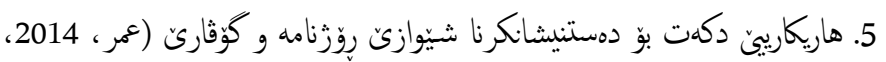

\section{4. تاييهمهندييّن زمانييّن مانشيّتّ}

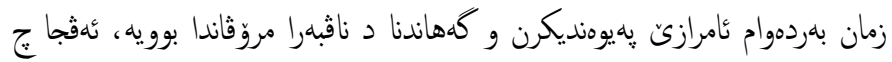

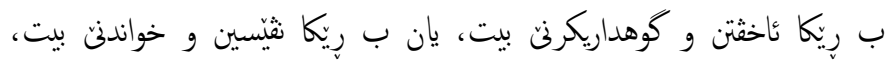

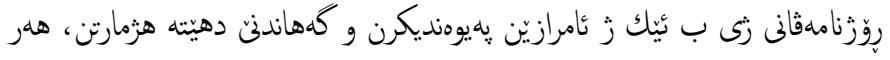

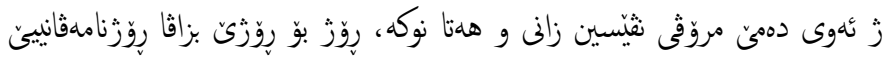

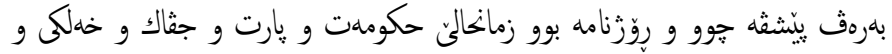

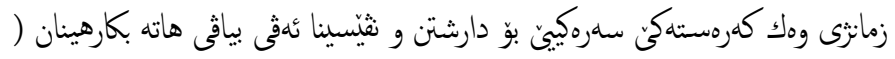

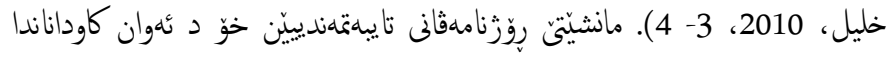
ومردكريت، ثٔويّن تيدا يهيدا دبيت و كهشه دكهت، هاووهسا كريّداى سروشتي 


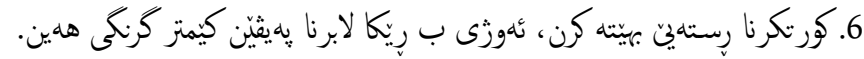

7.

.(153،2005،etal

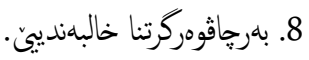
9. تاكه هزرهك تيّدا بهينته دارشتن. 10. مانشيّت ب بكةر نهديارى بهيته دارشتن.

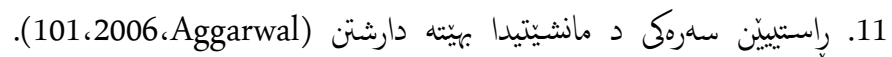

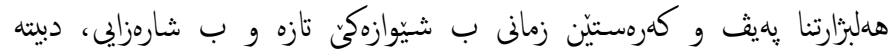

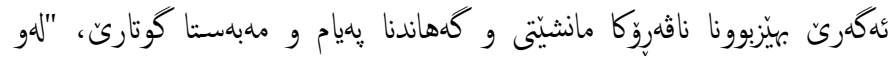

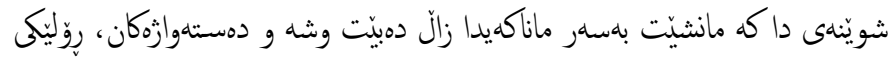

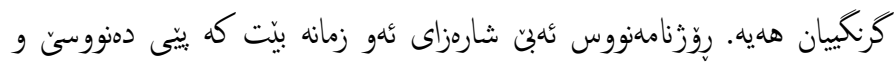

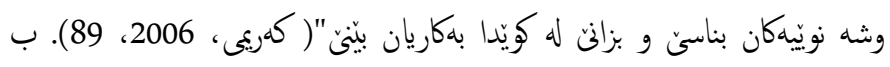

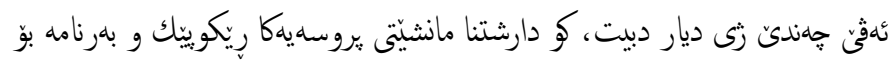

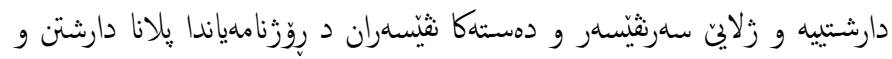
يبّشكيشكرنى دهيته دانان و مانشيّت بهرى بكههيته خواندهانى دهيّنه

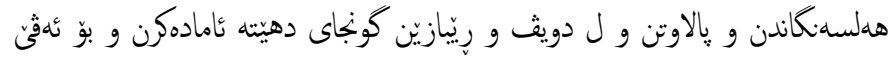
جهنديزّى بيكومان زمان وهو كمرهستهكي خاف، باشترين و كرنكزين ئامرازه بوّ

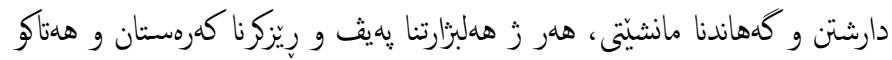

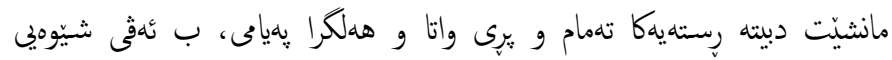

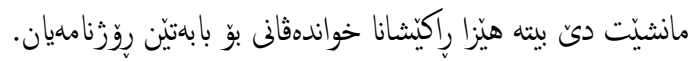

6. مانشيّت و مثازراندنا خواندهانى(وروورًاندن) بالكيشان، سهرنجان، ئازراندن يان ورووراندنا خواندهان و جهماوهرى و دروستكرنا رإيا كشتى و ب دمستفههينانا هلست و سوز و رِزامهندى و

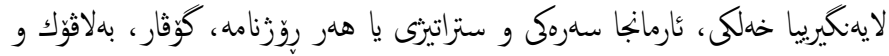

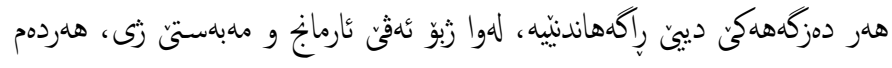

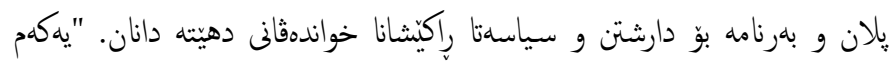

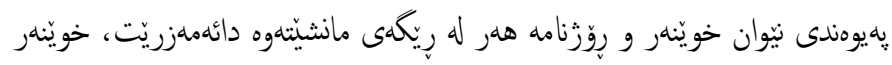

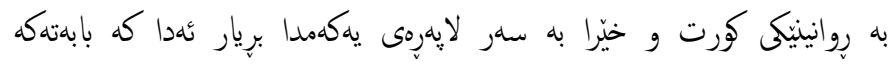
بخوينيتنهوه يان نا"( كهريى، 2006، 73). واته ئيكم ويستكههي ئيككهشتنا
ز دمستدهت و نمّوى رولى ناكيرِيت ينّ بوّ هاتييه دارشتن. 5. دارشتنا مانشيّتى : هلبثرارتن و يِّزكنا بهيث وكهرهستهيان

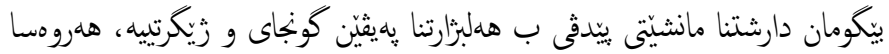

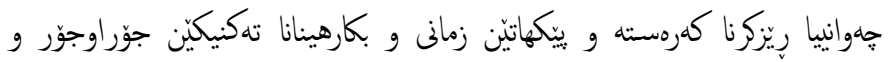

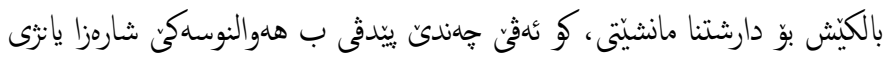
سهرثئسهرهكي هشيار و شارمزا د بياقيى زمانيدا هديه، جونكى دارشتنا مانشيتى كريارهك ئاسائ نينه، بهلكو كةلك كرنك و هدستياره و خالا رإكنشانا سهرنجا خواندهقانيه بوّ خواندنا بابهتى. داكو مانشيّت ين كورت و يوخت بيت، بيّدقييه د

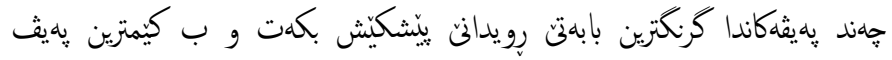

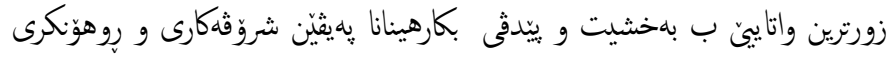
د مانشيّتيدا ناكهت، لئ كورتكرنا زاراثان وهك (ب.د.ك) و (ى.ن.ك) يا كونجايه

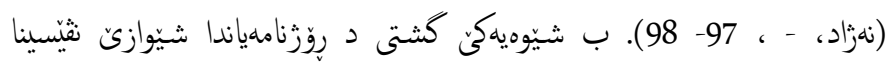

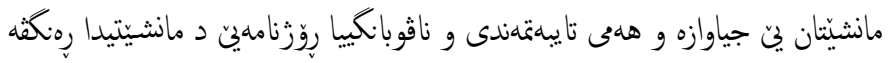

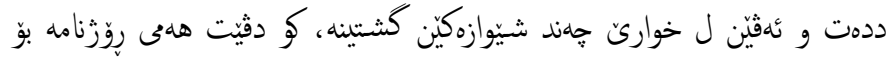

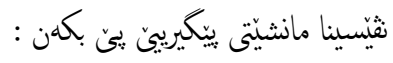

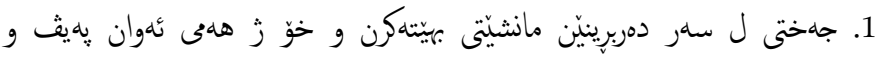
دمستهوازَّيّن، كو هيج مفايكك تيّدا نينه دوير بيّخن. 2. سهياندن وكركيدان ب كاريّ نهبورى د دمربرينيّن مانشيَّيدا، داكو خواندهثان ومسا هلست بكةت، كو ينّ د كمشى بابهت و رويدانيدا دريت.

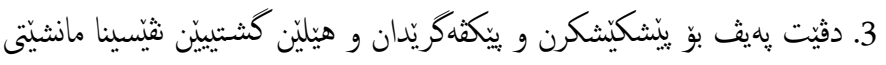
د كونجاى بن ( حزه : 1958، 130- 131). زيّدهبارى نئو خاليّن ئاماثه بئ هاتييه دان، كو ييّدثيه د مانشيَتيدا هلبن، دقيّت مانشيّت زز هندهك كيّاسييان بهيته دوير

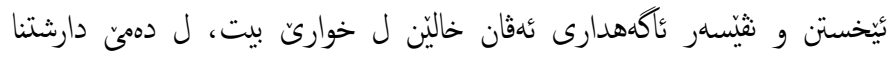

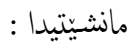
1. نافونيشانيّن دناقيُيكداجووى(متداخل). 2. بقن نرخى و بحن كهلكييا مdسهلي. 3. كيمييا هويركارييّن كرنك. 4. ثهكهراندنا رِويدانان بوّ ياشقه. 5. ب شاشى وهسفرن (على، 2004، 31-32). 


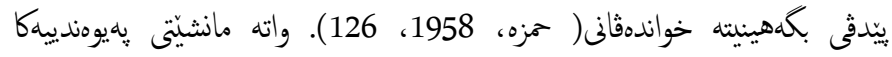

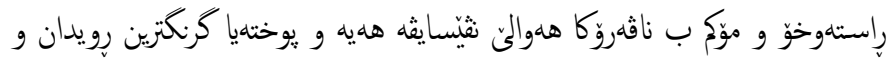

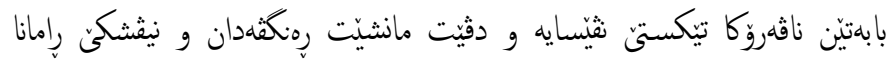

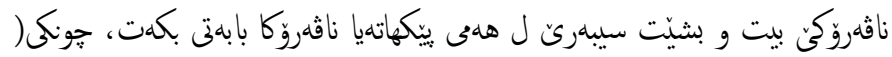

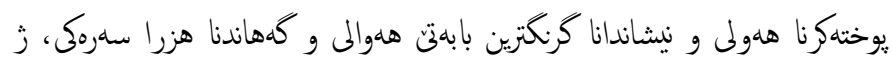

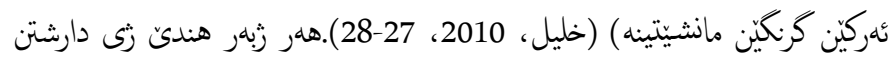

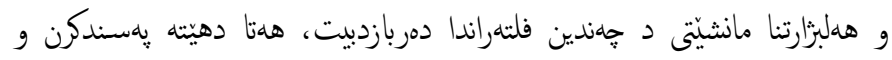

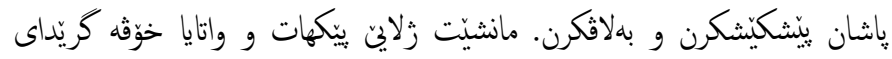

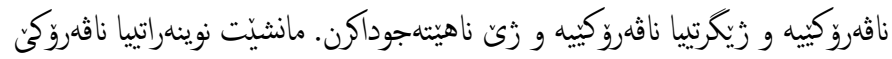

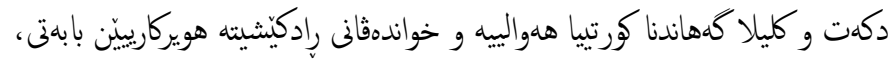

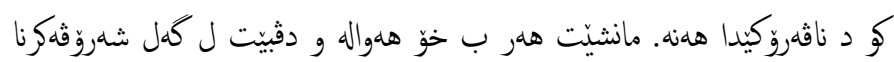

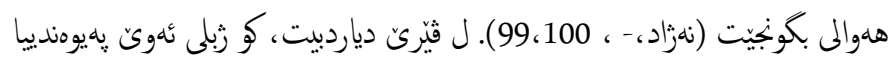

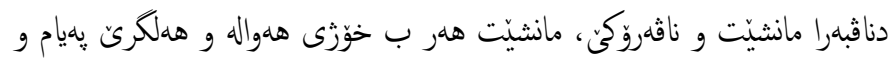

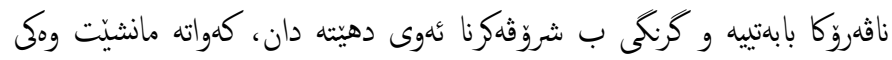

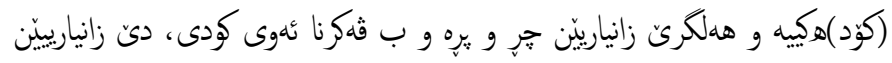

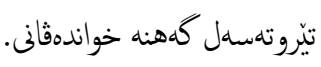

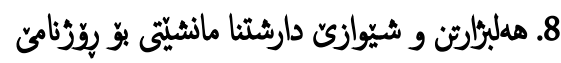

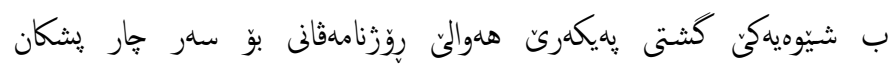

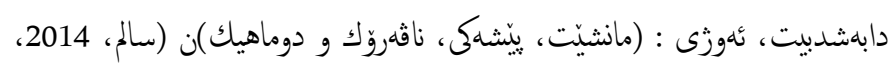

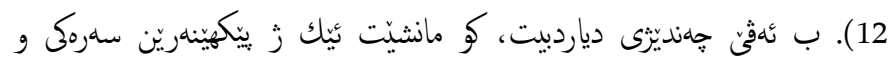

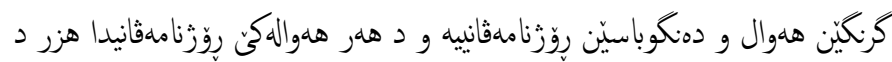

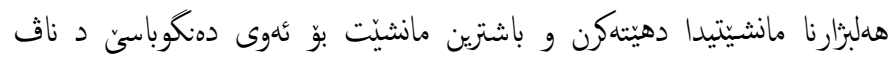

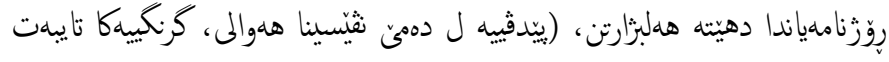

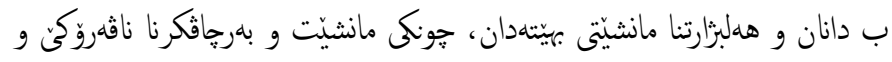

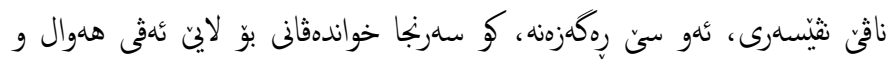

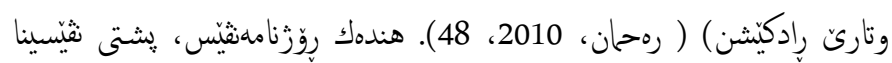

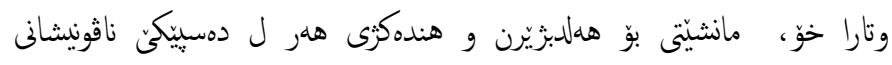

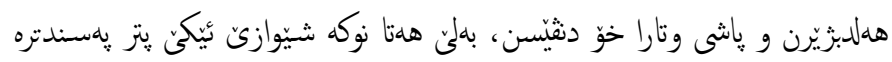

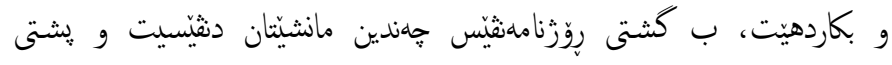

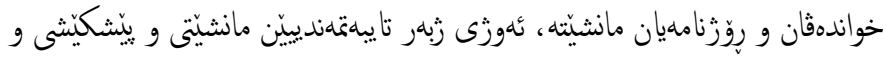

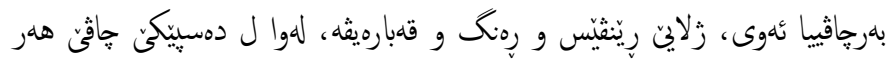

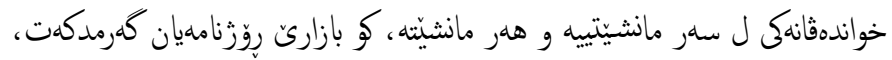

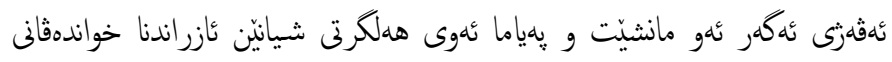

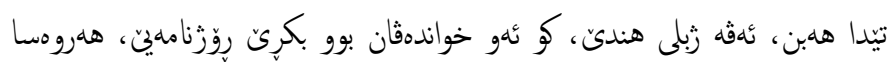

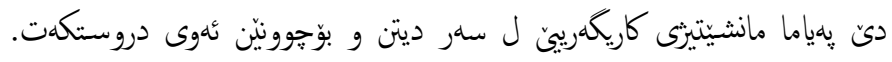

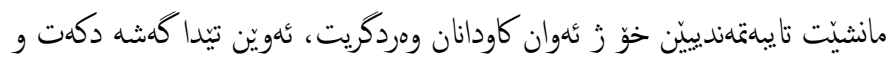

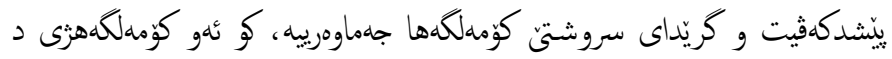
ناف خودا ز جهندين ييّكهات و كؤمليّن جودا جودا يِّكهاتيه و هلر ل كل

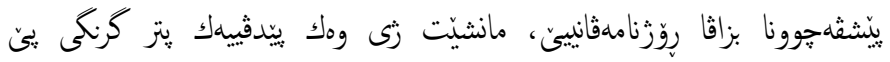

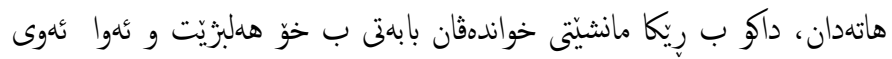
دقيّت بخوينيت و زانيارييان ل سهر بويهر و رويدانان وهركريت ( عهلى، 2014،

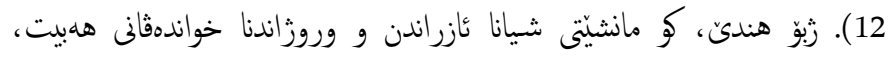

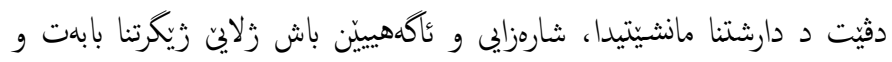

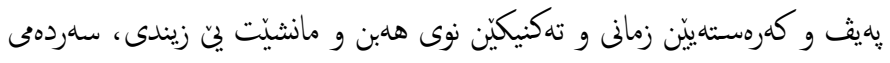

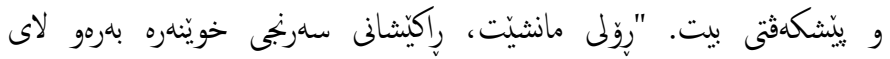

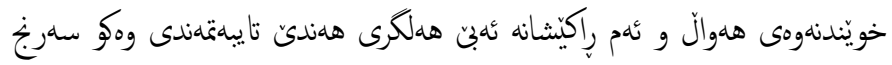
راكيشان، تازميى و تهبليغ بيّت. ليّهاتووى له بوارى ئاشنايهتى لدكل وشهكان و شيّوازى نوسيندا كليلى سهركهوتنه له مانشيّت نوسيندا"( كهريى، 2006، 89). لهوا مانشيّت ب كةرهستي ئازراندن، هشياركرن، ورووزاندن، راكِيشان و خالا سهريج و

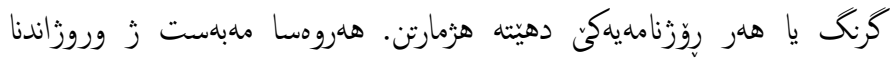
خواندهثانى، دروستكرنا رايا كشتيه ل سهر مثار يان هلر بابهتكى، رايا كشتى ئهو دهربرينهيه، ياكو مهبهست زئ دروستكرن و ب دمستقههينانا بوّجوون و رِازيبوونا

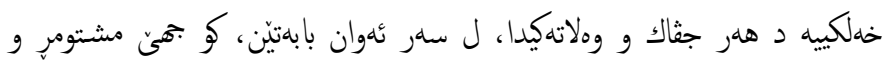
كهنكهشهيينه، ومهو ديتن و بوّجوون و بيروباوهر (كمال، 2012، 21). 7. بهيومندييا مانشيّى ب ناقهروكيثه د رِوَزنامهقانيا نويدا، هلمى شيان بوّ دارشتنا مانشيّتى دهينه مهزاختن، ب تايبهتى

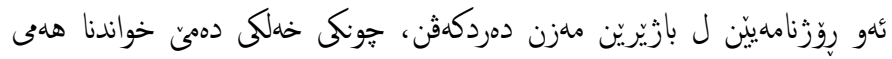

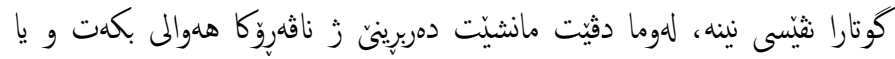


يا بابهتى و فهرهنكىى(كو ئدثه د سنوور و ئاستي سيانتيكيدايه) د هلمان دمدا

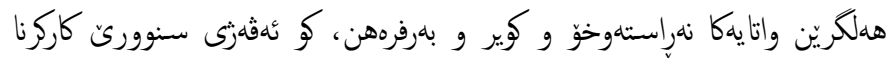

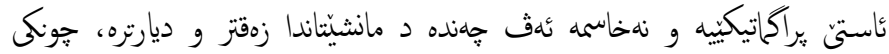

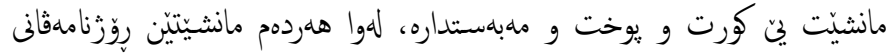

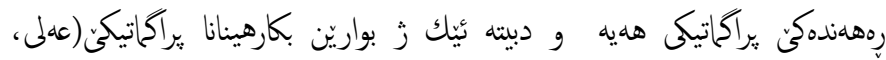
2014، 274). رولئ يراكماتيكى د فلتهركرنا زانيارييان د رِاكهاندنيّدا، ل دويث

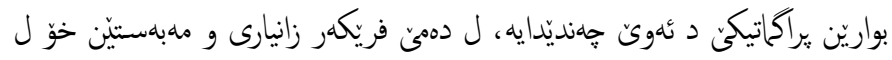

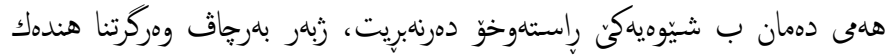
هوَكارين (سياسى، كوملايهتى و دمروونى...هتد) و ومركرى زى دى شيانين

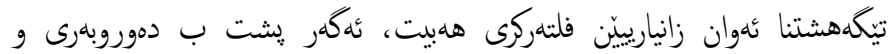

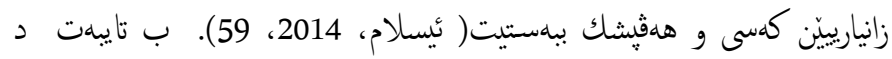

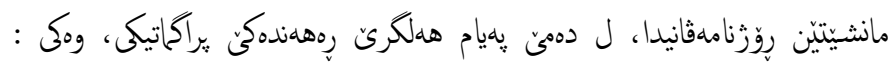

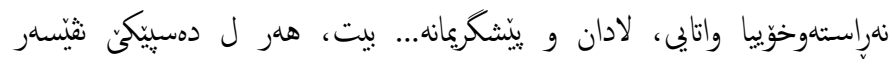

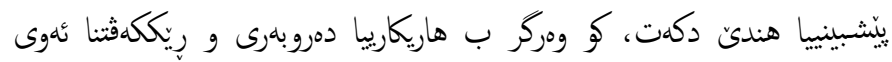
جثاكى و كاودانيّن هلى، دئ شيّت ل مهبهستا مانشيّتى بكههيت. مانشيّت د هلواليدا ب تنى ئيك مهبهست و ئارمانج نينه، بلكلكو جهند واتا هلنه( سهيان،

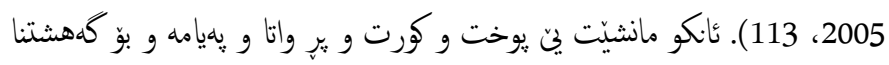

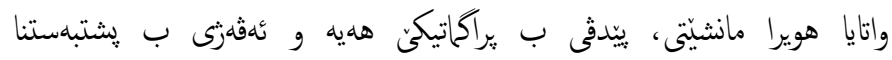

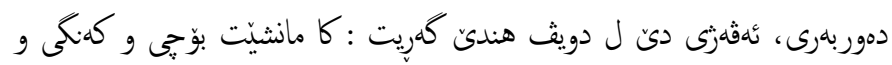

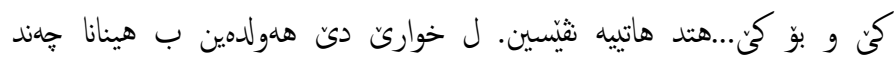

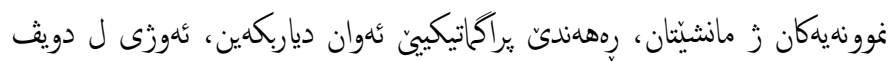

$$
\text { بواريّن براكماتيكى : }
$$

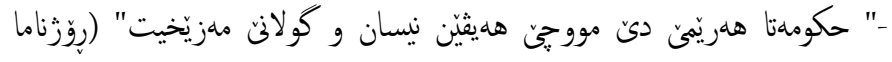
ئهفرو : ز) (1391)، ئيكشهمب 2014/4/13).

| 1أ. دمركفثته

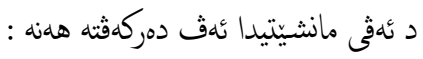

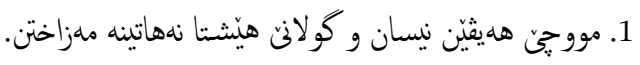

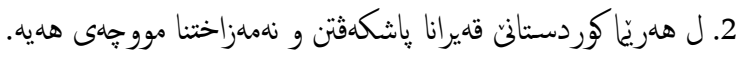

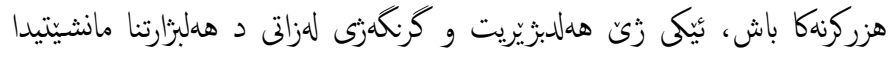

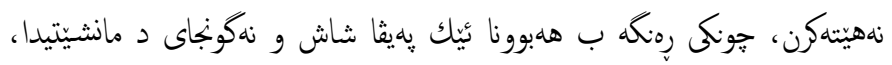

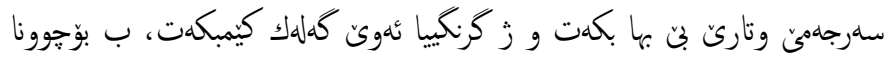

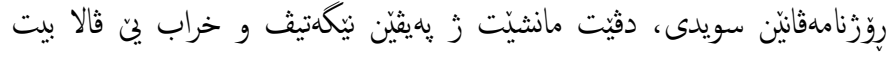

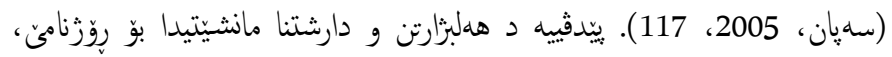
ئدف خاله ب بلرجاق بهينه وهركرتن :

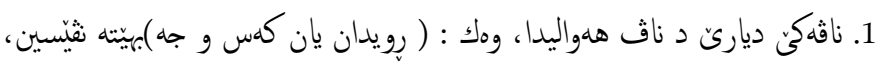
ل كهل تئيبيكرنا بكارهينانا ناسناقي ئهوى كهى.

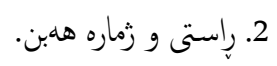
3. رويدان ومك خوّ بهيّته ثهكوهاستن.

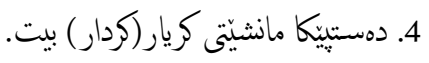

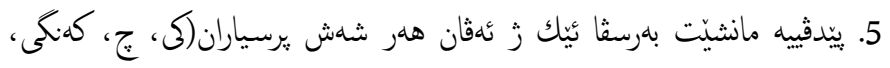

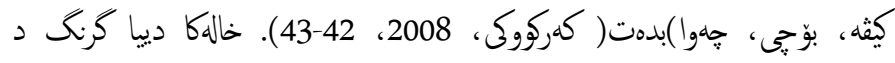

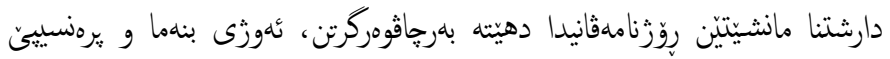

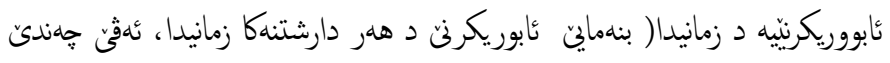
روهندكةت، كو ييّدثيه دارشتن ب كيمترين وزه بهينه ئهنجامدان، ب ثئفي

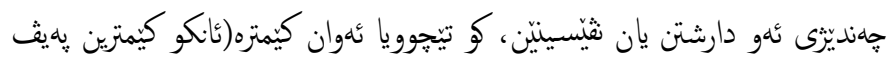

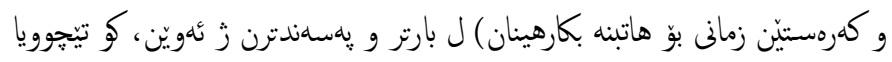
ئهوان يتز بيت) (رهسوول، 2014، 195).

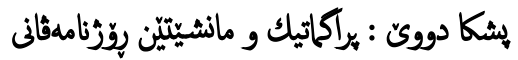

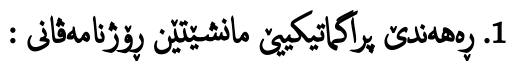

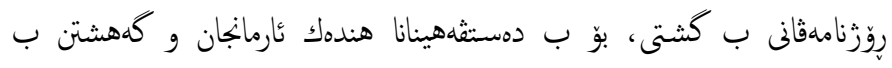
هندوك مdبهستيّن تاييهت دهيتّه بكارهينان، ئدقجا زبهرك زمان ب هلمى ييّكهاتين

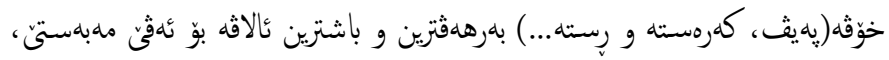

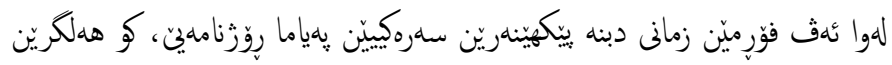

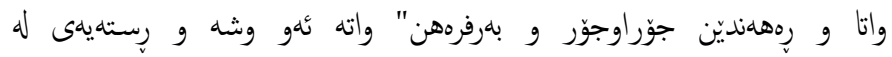

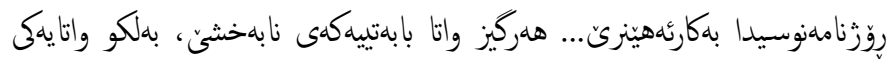
قولّتز و ئهفساناوى ترى هديه" ( ميسرى، 2009، 82). ئهقجا د شياندايه بهيته

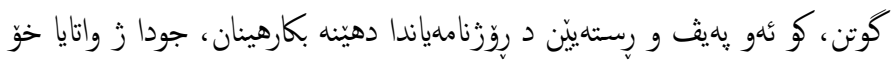




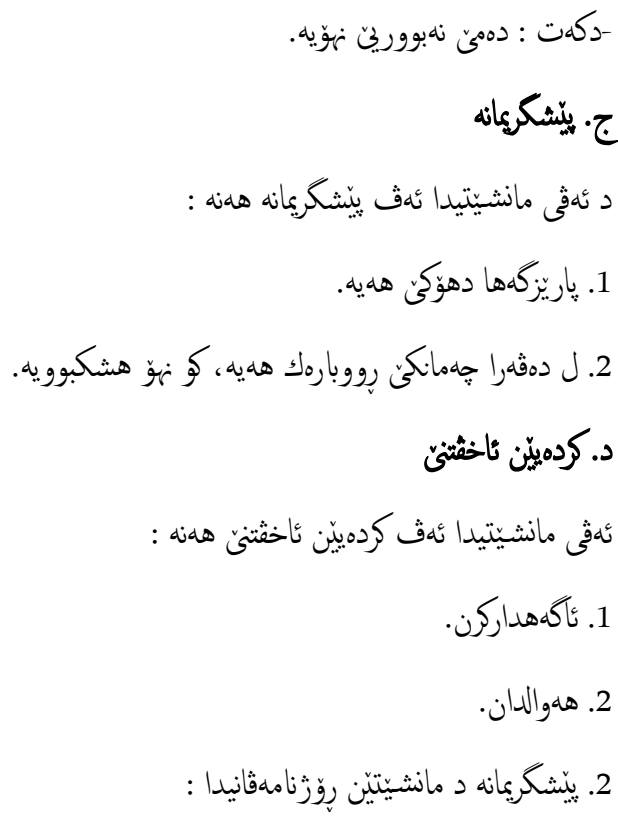

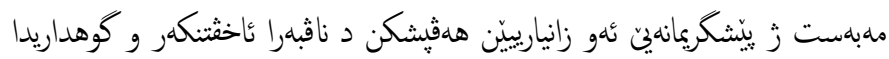

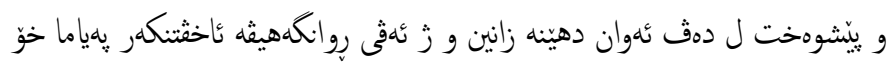

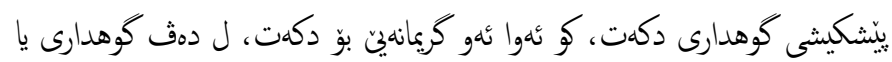

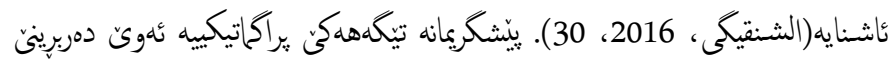

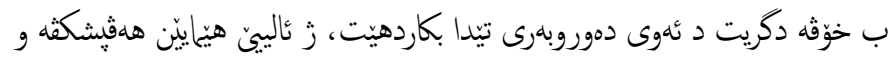
ييّن يِيّشوهت ل دهف ئاخثنتكمرى و كوهدارى ئاشنابن(شاهين، 2015، 20).

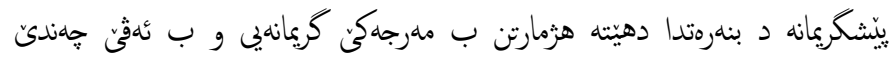
بهرجهستهكنا كوتنى تهواودبيت. يِيشكريمانه بهرى هلر تشتهك مهرجه بوّ بكارهيناني و دشياندايه يِيشكريمانه وهك ناثةروك يان تشتهك د ناثا واتايا كوتنيدا بهزميَّرين و د

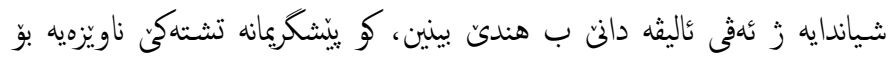

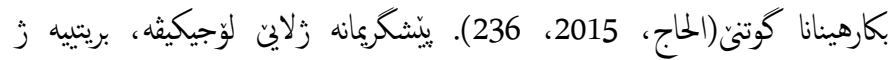
هلبوونا هيهيوندييهكا راستى د ناقبهرا دوو كوتناندا، يانزى هليلينجان و يالاوتنا

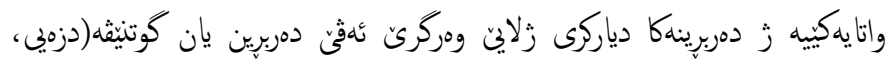

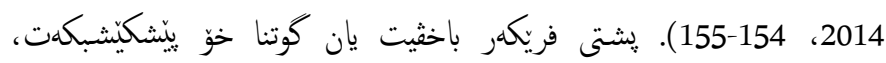

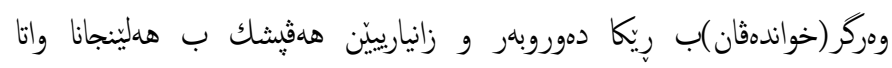

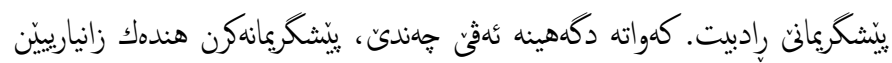

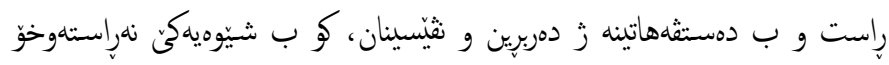
يان ثهشارتى هاتينه كهاندن و فريكمر و وهركر(خواندهان)زى ل سهر ئهوان

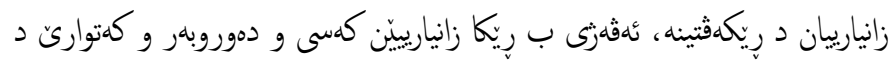

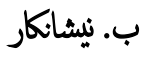
د ئهقى مانثيّتيدا ئهف نيشانكاره هلنه :

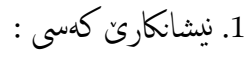

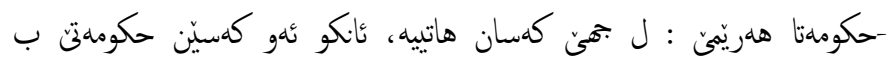
ريّمهدبن.

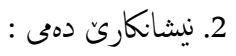
-دى ملزيّخيت : دمدى نهبووريه. -نيسان و كولان : هليثينّ جار و يِينّج.

ج. بيّشكرعانه د ئهقى مانشيِتيدا ئهق يُّشكريمانه هله : 1. حكوملتا هلريَّى هليه.

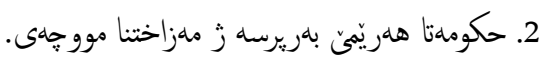
د. كرديلّن ثاخقثنى د ئهقى مانشيّتيدا ئهف كردهيّن ئاخثتنى هلنه :

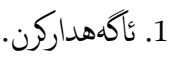

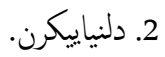

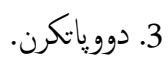

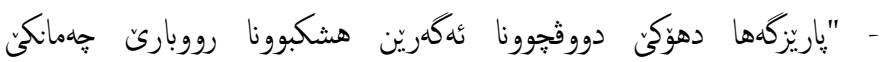
دكهت"(رِوَزناما وار : زَ(1048، يِنْجشهمب، 27ى شوات، 2014).

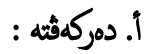
د ئهقى مانثيّيتيدا ئه دمركهقته هله :

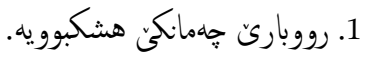
2. هشكبوونا رووبارى تهمانكى كاريكهرى ل سهر زيانا خهلكى ثنهوى دمثهرى د ئهق مانشيَتيدا ئه نيشانكاره هلنه :

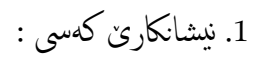

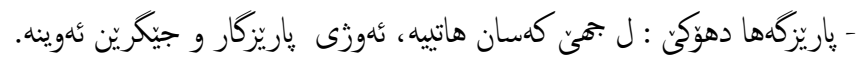

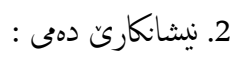


- كئدمريكا بهرى نوكه ئهث دوو حيزبه كبوونه د ليستا تيروَريّدا.

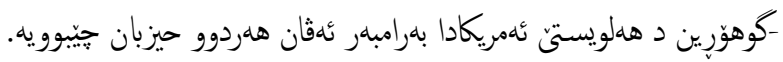

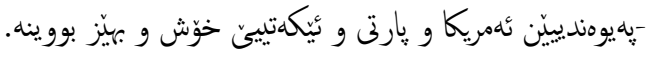

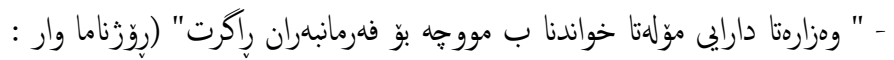
زم(1048، يِنجشهمب، 27ى شوات، 2014). دئدقى مانشيَتيدا ئدف يِّشكريمانه هله :

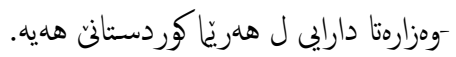
-بهرى نوكه ومزاروتا دارايى موّلهنا خواندنا ب مووجه ددا فهرمانبهران. - بارى دارايى و ئابوورى ين هلرينيّ باش نينه. -" 400 خيّزان ل كوّمهلكها خهليكان داخوازا بنكههكئ ساخلهميين دكهن" (روّزَناما وار : زُ(1048، يِّنجشهمب، 27ى شوات، 2014).

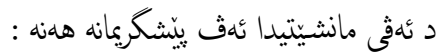
كؤمهلكههلك ب ناقيى خهليكان هليه.

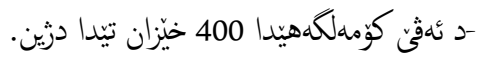

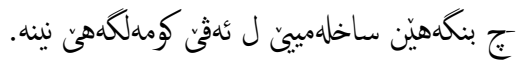

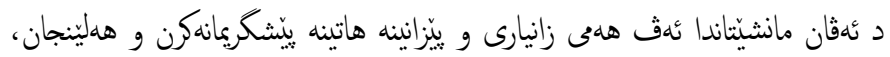

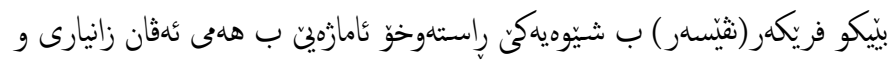
داتايان بدهت، جونكى ثئسهر بهروهخت دزانيت، كو خواندهثانى شيانيّن

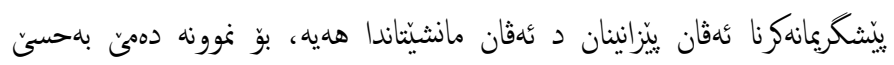

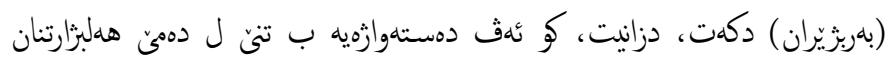

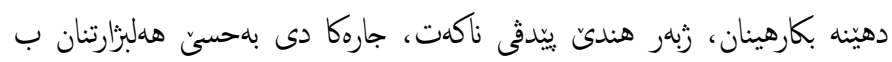

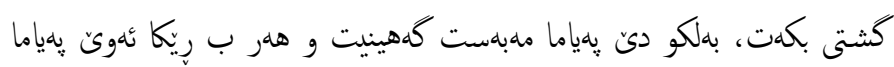
كورتكرى ههندين زانيارييّن دييّن قهشارتى د مانشيَتيدا دهينّه يِيشكريمانهكرن.

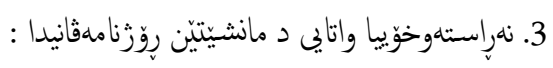

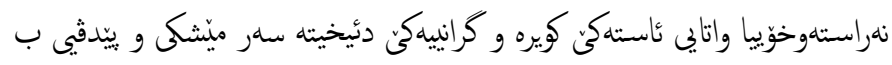

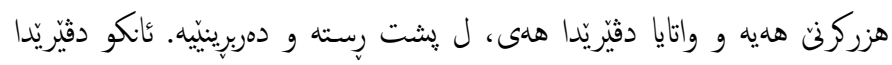

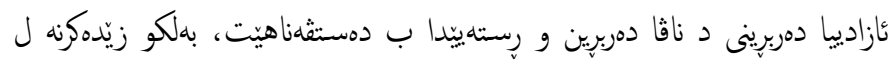

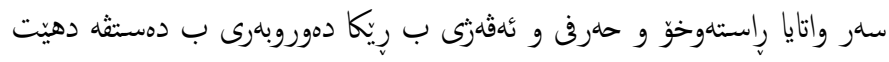

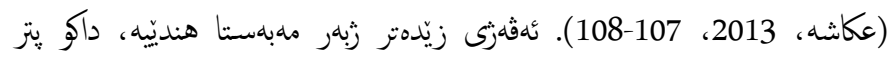

ناف ئهوى جقاكيدا هلى ب دمستفدهينّ و يِّشكريمانهكن ب تايبهتى د مانشيَتينّ

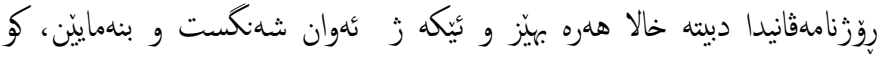

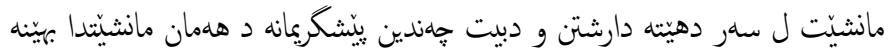

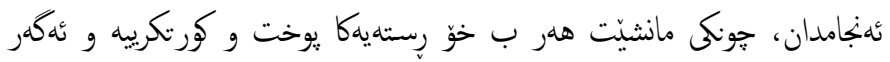

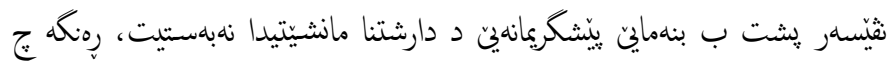

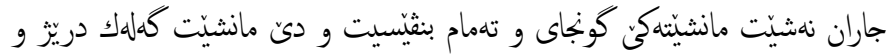

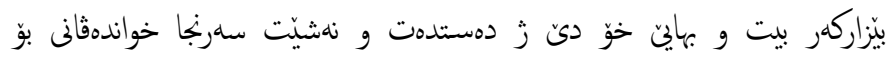
كزنكزين رِويدان و هلواليّن د ناثا وتاريّدا رابكيشت . ئانكو دكههينه هندئ كو

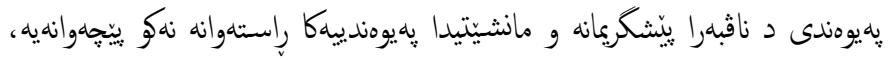

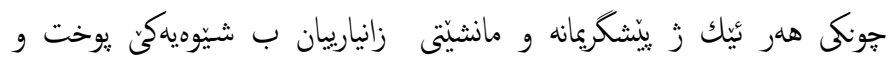

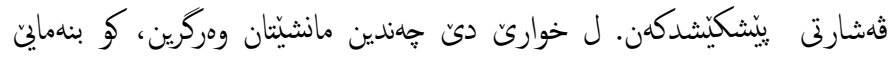

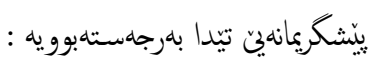

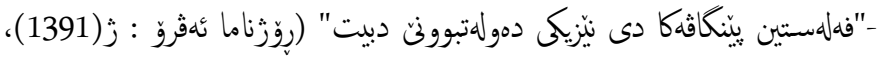

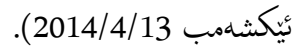

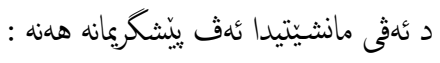
-وملاتهك ب ناقيى ففلمستين هليه. ففلهستين هيّشتا نهبوويه دمولهت.

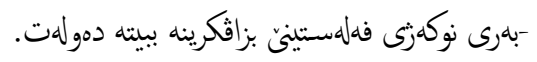

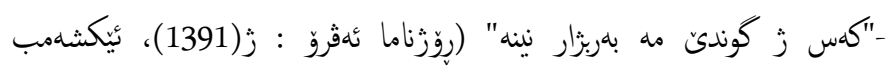
.$(2014 / 4 / 13$

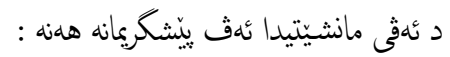

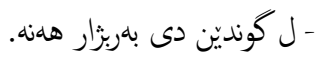
-بهربثاركن ل دويث بنهماين كوند و عهشيروتى دهينه دياركرن. - بروسهيا هلبثرارتنان هليه.

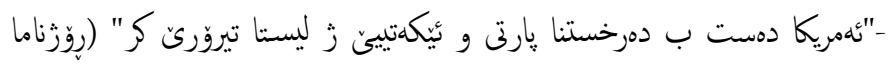
ئهروّ : زم(1391)، ئيكشهمب 2014/4/13).

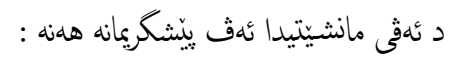
- ئهمريكا ومك وهلاتهكى زلهيّزى جيهانَ هديه. -دوو حيزبيّن كوردى ب ناقيى (يارتى و ئيكهتى)هلهن. 


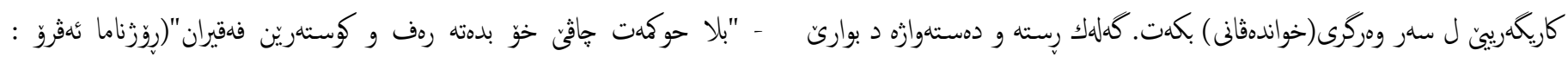

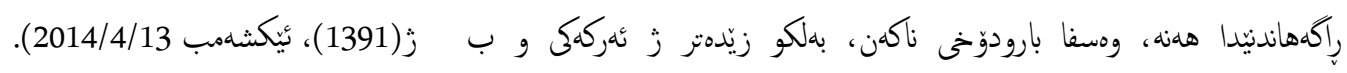

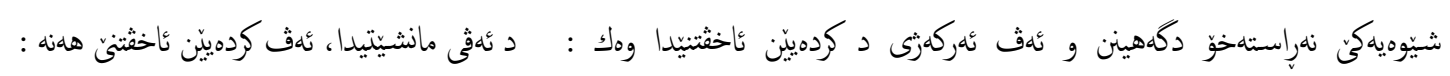

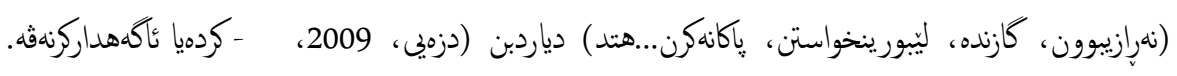

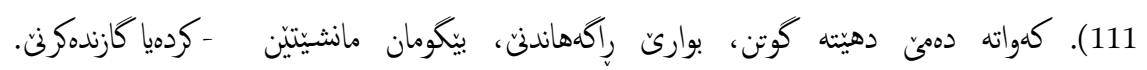

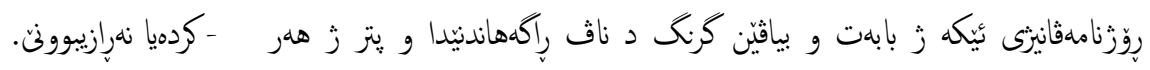

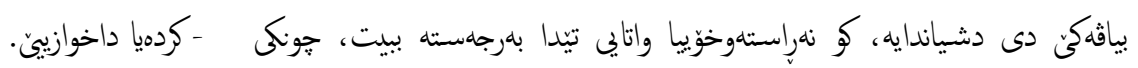

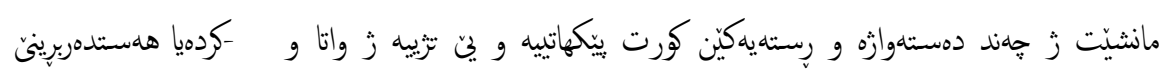

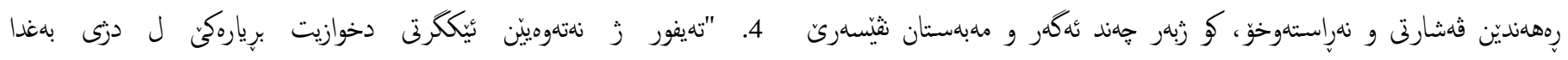

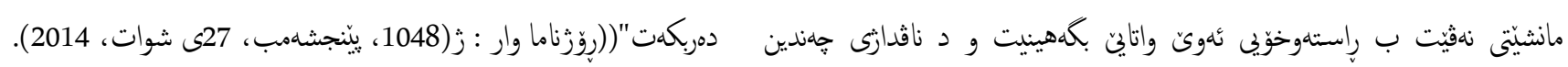

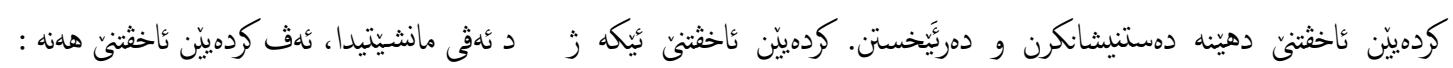

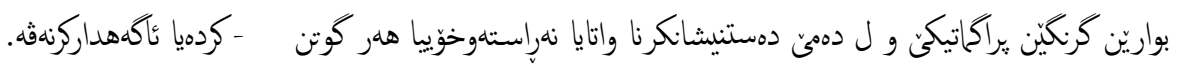

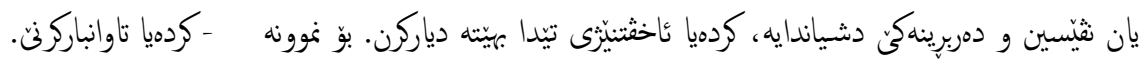

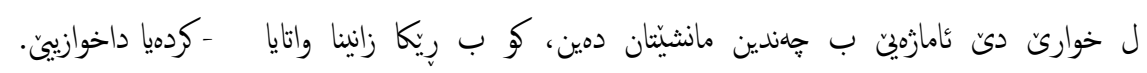

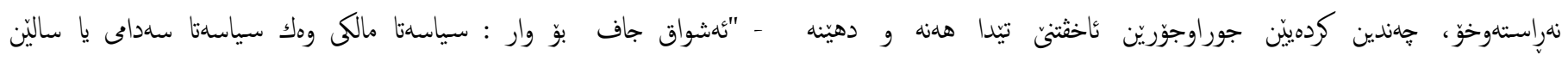

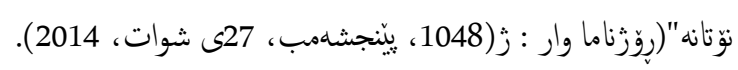

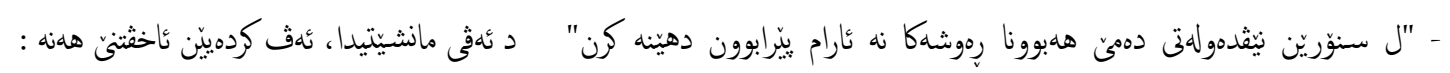
- كودميا نأكهداركنهث.

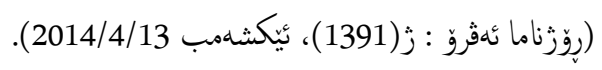
- كردميا تاوانباركنى.

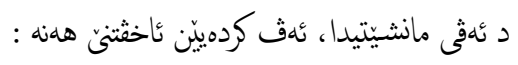
- كردهيا نهرإزيبوونه. - كردميا ئكهداركنهثه. -كرديا كازندهركن. -كردميا هوَشدارى.

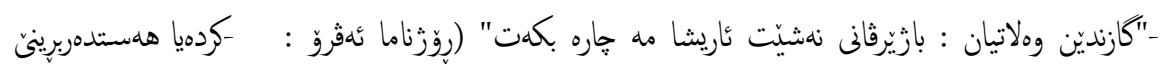

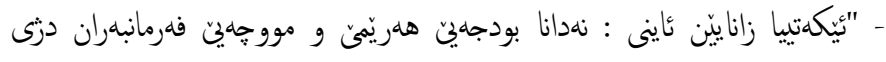
ز) ز) (1391)، نيكشهمب 2014/4/13).

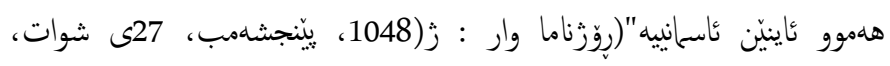

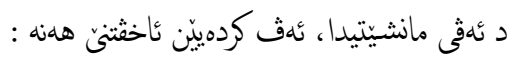
.)(2014

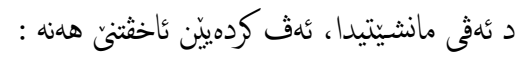

$$
\begin{aligned}
& \text { - كودميا ئكهداركنهثه. } \\
& \text { - كرديا كازندهكنى. } \\
& \text { - كرديا تاوانباركنى. }
\end{aligned}
$$

$$
\text { - كردميا كازندهكنئ. }
$$




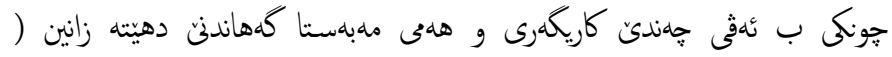
أرنست، 2014، 180). همروهسا لادانيّن واتايى د بنهماين هاريكارييّيدا دهينه ئنجامدان، جونكى هلمى دمان د شيانا فريكةرى يان نثيسهريدا نينه، بنهماين

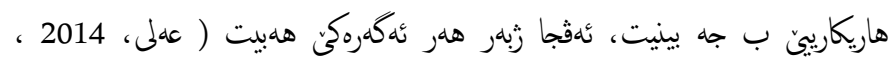

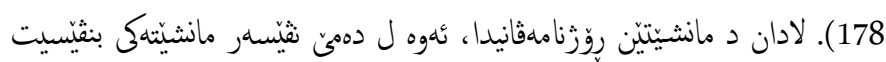

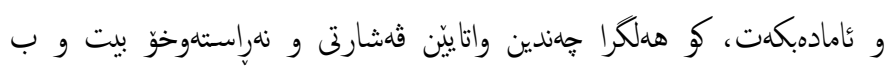
هاريكارييا دمركمثنهيان و هشتبهستنا دموروبهرى ئدف لادانين واتايى دهينه دهستنيشانكرن. هلر ل دمستينيكي دمهي خواندهان مانشيتى دخوينيت، لادانيّن وانائي تيّدا دياردبن. وهو د دئدقان مانشيّناندا دياردبيت : - "جهمال بروارى : مه هندهك تشت ل راديوّيا بهغدا دكرن بهلكو ئزّكى دهنكي

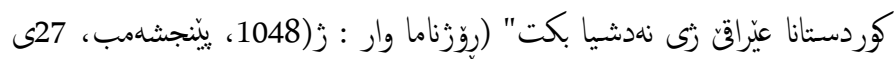

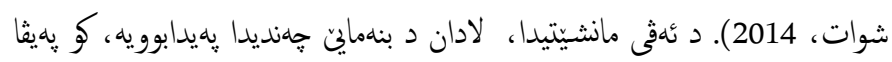

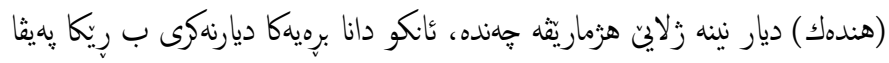
(هندهك). ديسان لادان د بنهماتِ جهوايى زيدايه هليه، ئهوزى نرخاندنا ئزئكى كوردييه ل بهغدا. ديسان لادان د بنهمايت شيّواز ريدا هليه، تونكى دريّزدارى تيّدا

ه

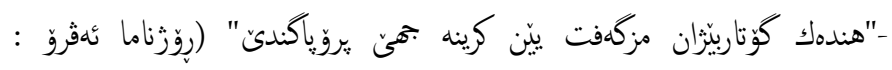

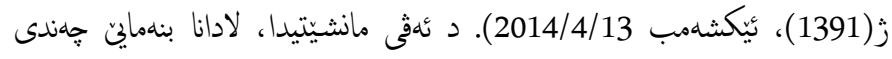

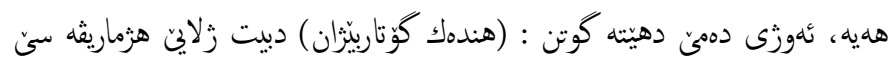
بن و دبيت دهه زى بن، يان يتر يان كيمتر زى بن، كهواته ئه بنهمايه هاتييه لادان. ديسان لادان د بنهمايتّ جهوايق زيدا هليه، جونكى هُيامهكه ب تاوانباركرنا

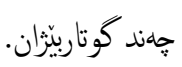

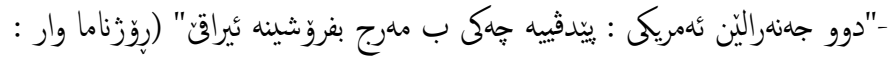

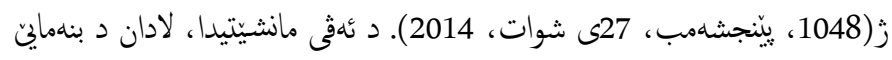

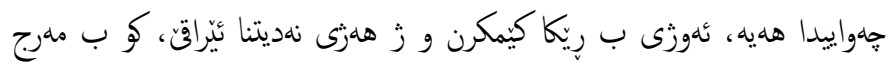

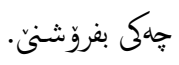

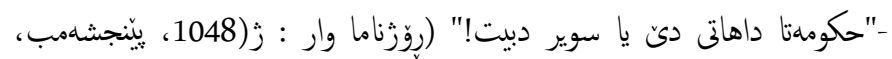
27 (27 - nى شوات، 2014). - كردميا هلستدمربرينى.

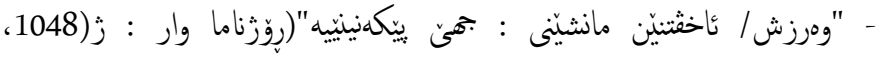

$$
\begin{aligned}
& \text { يِّنجشمب، 27ى شوات، 2014). }
\end{aligned}
$$

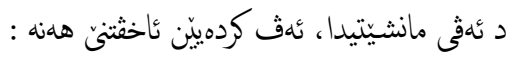

$$
\begin{aligned}
& \text { - كردهيا توانجليدانت. } \\
& \text { - كردميا نهرازيبوونَّ. } \\
& \text { - كردميا سهرسوّرمانَ. } \\
& \text {-كرديا كازندهكرنّ. } \\
& \text {-كردميا هلستدهربرينى. }
\end{aligned}
$$

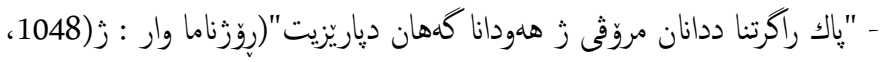

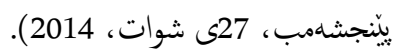

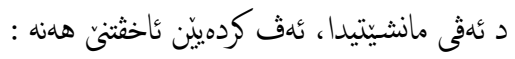

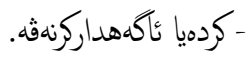

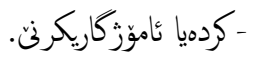
-كردهيا داخوازييى.

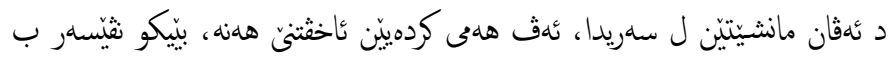

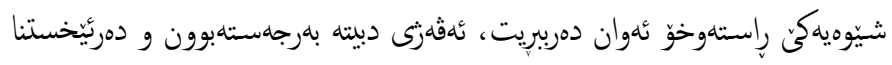

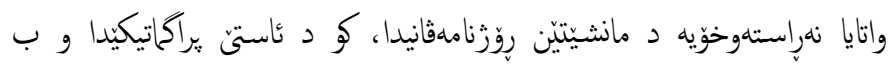
هاريكارييا كردييّن ئاخثتنى هاتينه دهستنيشانكرن.

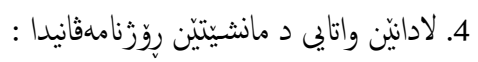

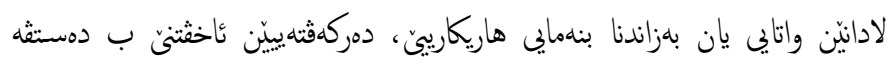
دهينيت( أحمد،2012، 88). كهلكجاران د زمانَ راككهاندينيدا، زبو كاريكةرييهكا

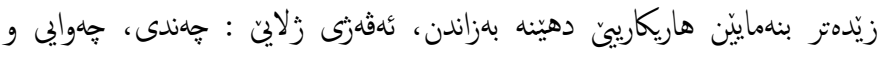
شيّواز...هتد دهيّنه ب جمهينان ( دزميى، 2009، 121- 122). زبهر هندين

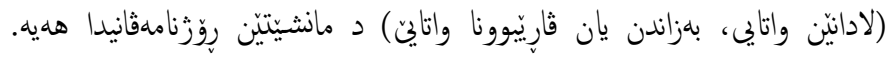

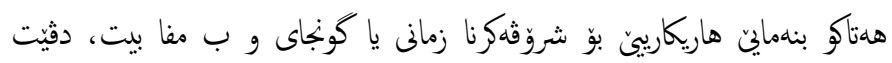

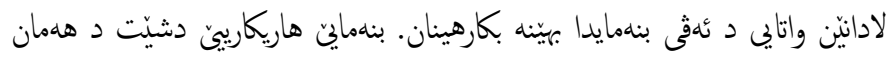

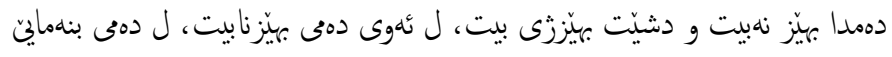

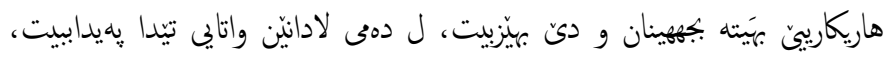


-شارززايهكي ثنابوورى : هلبوونا بودجا خيّزانى د قهيرانين ئابوورى دا كرنكه"

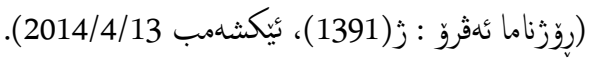
د دئهى مانشيَتيدا، ئهق نيشانكارى دمى هليه : -د قهيرانين نابوورى دا : نهبهست يتى ثنو قهيرانا ل 2014 يهيدابووى، كو ههنا نهو

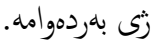

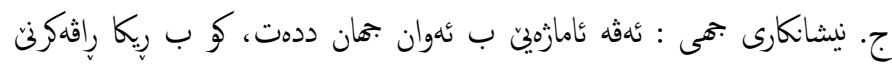
جمئ ئاخثنى دهيتّه زانين. وهك :

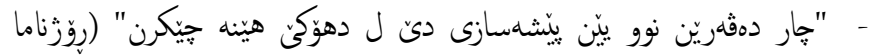
ئدثرو : ز)(1391)، ئيكشهمب 2014/4/13).

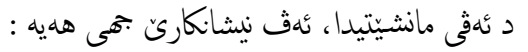
لـ دهوَكى : باريزّكهدكا كوردييه ل كوردستانا عيراقَ.

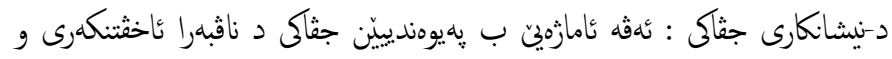

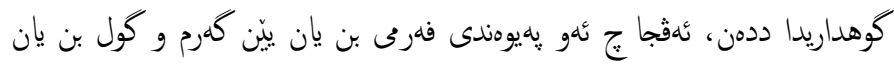

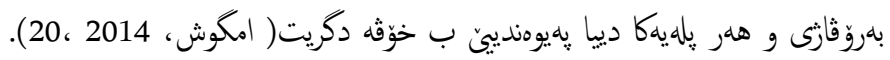

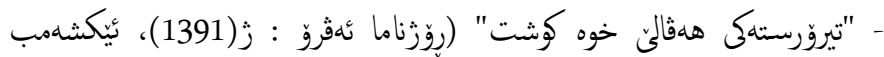
د دئفى مانشيتيدا ئدف نيشانكارين جقكى هلنه

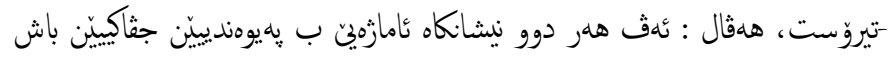
و خراب ددهن، كو (هلفال) باشييئ رادكههينيت و (تيروّرست) خرابييى دكهنينيت.

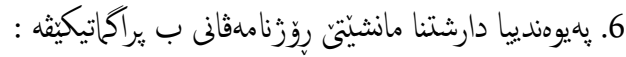
كلهك جاران دارشتن و قهبارئ ثهاندنا مانشيتى بهيوهندى ب براكماتيكيثه هديه، جونكى فهباره و تهكتيكا شهاندنا مانشيتى كاريكةريين ل سهر خواندهانى دكةت و

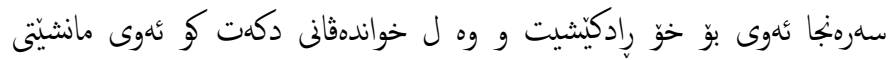

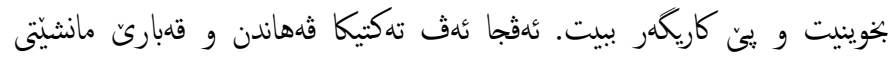
دووجار وه ل خواندهانى دكةت، كو ب ئدوى مانشيتى كاريكةر ببيت، جونكى

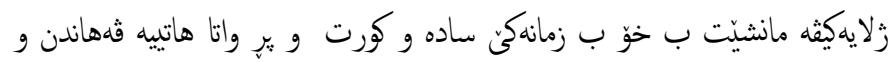

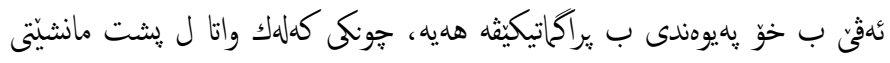

د ندفى مانشيتيدا، خواستن هليه، خواستن زى دبيته لادان د بنهماين جهواييدا،

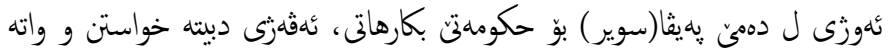

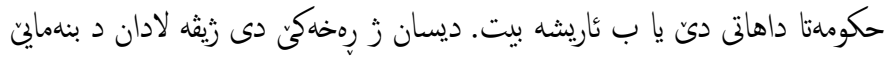
جهواييدا يهيدابوويه، ئهوزى ب رِيّا كيمكرنا حكومهتا داهاتى.

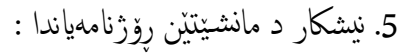

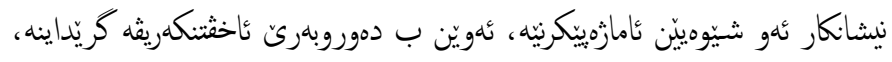

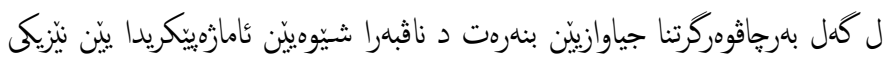

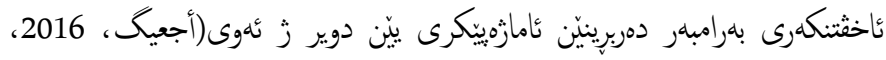

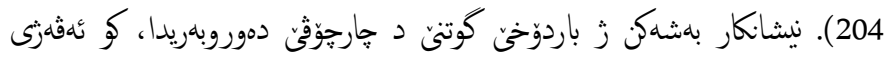

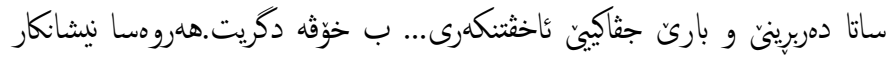
بهشهك ز زويدانيّن ئاخثتنى و د هلر زمانهكيدا ئهف نيشانكاره هلنه، كو بريتينه ز يهيث و دمربرينان و يشتبهستنهكا تنواو ب ثندوى دموروبارى دكفن ثنويّن تئدا بكارهاتين و دشياندا نينه بهيينه بهرههمينان يان رإثهكن دوير ز دموروبهرى. ئهث

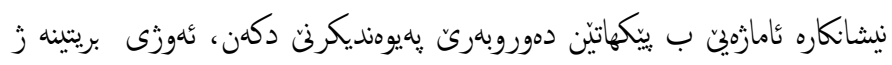

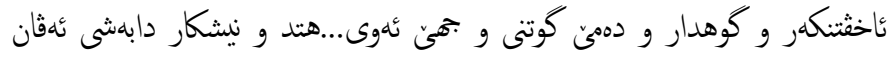

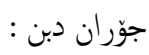

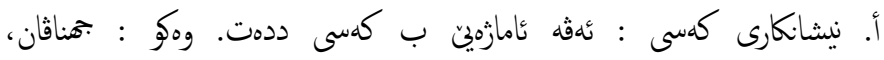
ناقان...هتد(امكوش، 2014، 19-20). ليثنسن ل دور نيشانكاريّن كمسى دبيّزيت :

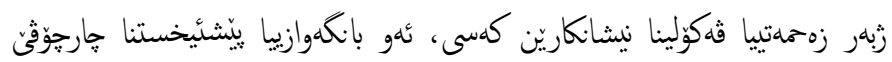
تيوزرى و يراكتيكى دكمت، كو قدكولينا نيشانكارين كهسى ل دهمي دانوستاندنّ يا

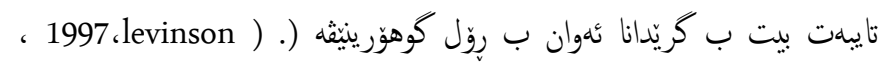

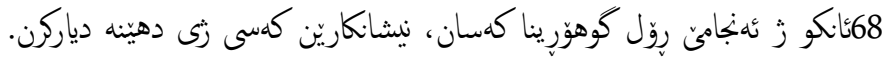

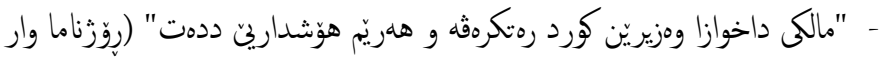
: ز زم(1048، يِّنشهمب، 27ى شوات، 2014). د دئقى مانشيّتيدا ئه نيشانكارئ كهسى هليه :

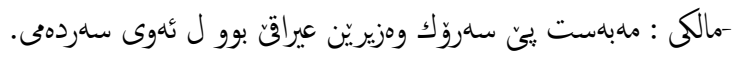

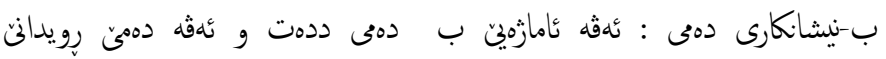

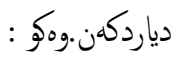


6. دارشتنا مانشيّتى ثهيوهندى ب يراككاتيكيثه هديه، جونكى تهكتيكا قههاندنا

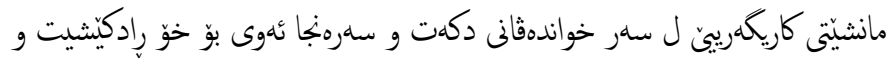
وه ل خواندهانى دكهت كو ئهوى مانشيّتى بخوينيت و يني كاريكةر ببيت.

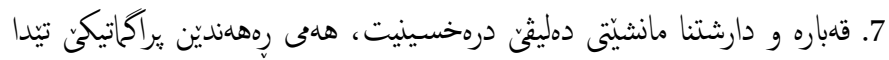
رo ليستا زيّدمران

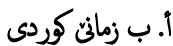

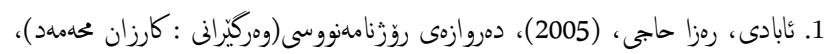

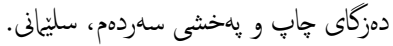

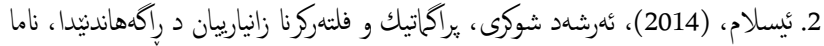

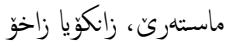

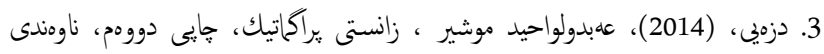

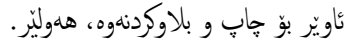

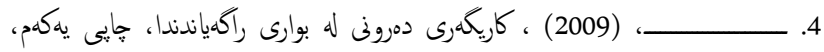

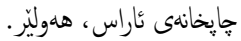
5. رِسوول، سهلاح حهويّز، ، (2014)، يرهنسييى به ئابوريكردن له زمانى كورديدا،

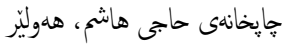

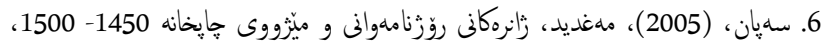

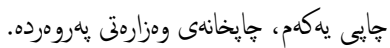

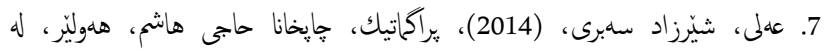

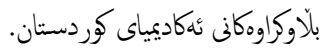

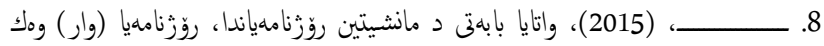

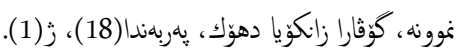

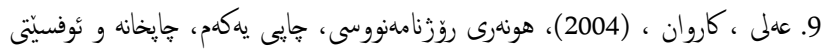

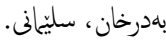
10. كهركوكى، حهبيب، (2008)، هوننرى رؤرنامهنووسى(وهركيراني: سمميره ئهمدد)،

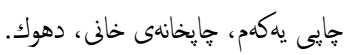

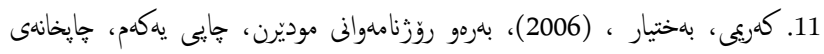
12. ميسرى، محمد دليّر امين، (2009)، زمانى شيعر و زمانى يوزّزنامنووسيى، كوفارى ومزارنت يهرومرده.

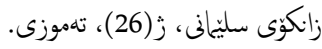

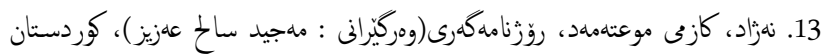

نيت (Kurdistan net).

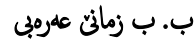

1. أجعيط، نورالدين، (2016)، الوفائف التداوليه للتخاطب السياسى و أبعادها الحجاحية، الطبعة الاولى، الناشر : عالم الكتب الحديب للنشر و التوزيع، أربد-الاردن.

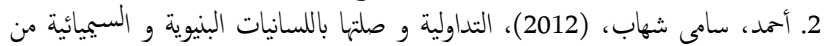

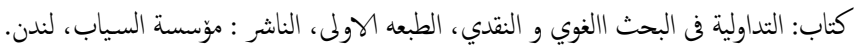

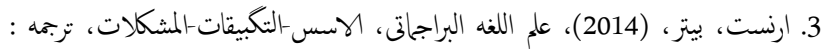
سعيد حسن البحيرى، الكبعه الاولى، مكتبه زهور الشرق ، القاهره.

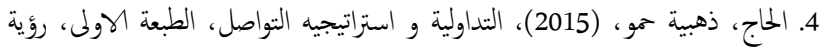

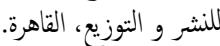

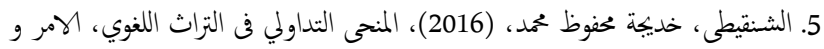

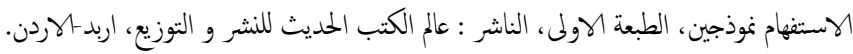

هانه و دهليقه بوّ كوهدارى دهيليت، راقهكينّن زيّكجودا زئ ببهت و ينى كاريكةر ببيت و زلايهكى ديثه قهباره و تهكتيكا قهاندنا مانشيّتى، خواندهقانى بوّ خوّ رادكيشيت و وه لي دكةت زيّدهتر ب مانشيّتى كاريكةربيت و يِيّفه بهيّته كريّدان.

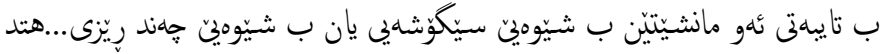

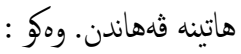
روسيا ياريهكا"ملترسيدار

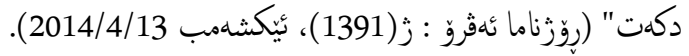

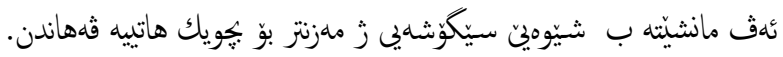
"دهـوَكى كَرتيَن دهنكانَّ وهركتينه" (رِوَزْناما وار : زَ(1048، يِّنجشهمب، 27ى شوات، 2014).

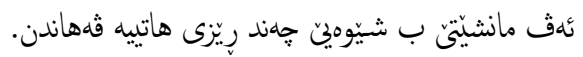

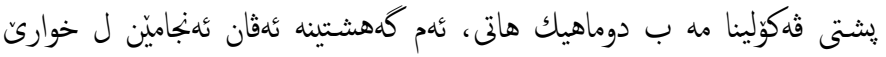

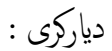

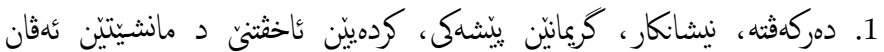
روّزَنامهياندا هلنه.

2. يهيوهندى د ناثبهرا يِيشكريمانه و مانشيّتيدا، يهيومندييهكا راستهوانهيه، جونكى هلر دوو زانيارييان ب شيّوهكى قششارتى بيّشكيّشدكن.

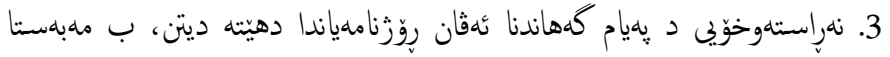

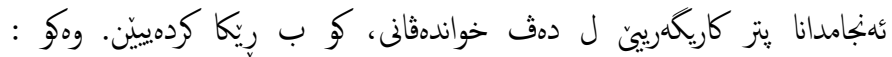
(نأكهداركن، ه هستدهربينين، كازندهكرن، تاوانباركرن، توانجليدان، نهرازيبوون، سهرسورماني، هوَشدارى، داخوازى) ئه كاره دهيته نهنجامدان.

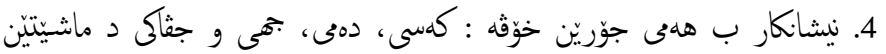

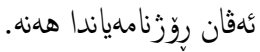

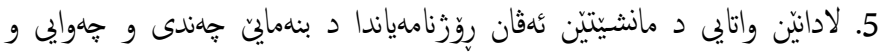

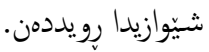




$$
\begin{aligned}
& \text { 6. امطوش، محم، (2014)، التداولية، مقربات فى المفهوم و التاصيل ، الطبعه الاولى، دار } \\
& \text { نيبور للطباعة و النشر و التوزيع، الديوانية- العراق. } \\
& \text { 7. حمزه، عبداللطيف، (1958) : المدخل في فن التحرير الصحفى، الطبعه الثانيه، دار } \\
& \text { الفكر العربى، القاهيرة. تمزه عبل } \\
& \text { 8. خليل، لؤي، (2010) : الإعلام الصحفي، الطبعة الاولى، دار أسامه للنشر و التوزيع، } \\
& \text { عمان 9. - مالودن. } \\
& \text { 10. سالم، محد سامى صبري، (2014) ، ماده الخبر الصحفي - قسم الاعلام التربوي - } \\
& \text { كلية التربية النوعية - جامعه دمياط. }
\end{aligned}
$$

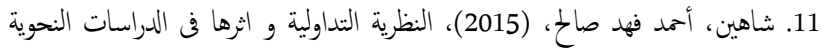

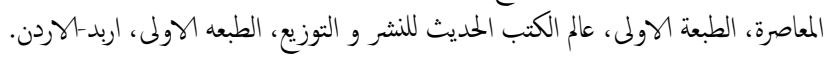

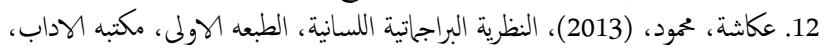

$$
\begin{aligned}
& \text { القاهرة. } \\
& \text { 13. عمر، هاوزين، (2014)، المقالة الصحفية، اتجاهات - بناو و لغة، الطبعه الاولى، }
\end{aligned}
$$

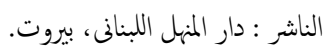

$$
\begin{aligned}
& \text { 14. كمال، محمد مصطفى، (2012)، الإعلام الدولى و الرأى العام، الطبعه الاولى، دار }
\end{aligned}
$$

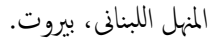

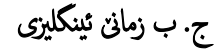

1. Aggarwal،V.B(2006).

Essential for practical Jornalisim.Nawdelhi concept.

2. Bell، A(1991). The Language of News media. Oxford. Blackwell.

3. Friend،C.، Ctiallenger، \& McAdams Lc.c(2005). Contemporaam Editiry. 2nd. Newyork. McGraw-Hill.

4. Levinson.S.C، Pragmatics، Campridg، Campridge University Press، 1997.

5. Turow، (2009). Media Today : An introduction to Mass communication.3red. Newyourk.Routledge.

6. Van Dijk، T.A(2007). Didscourse studies. London : Sage.

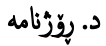

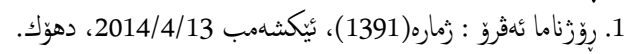

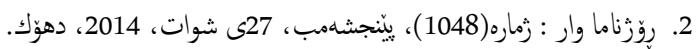

